\title{
Facilitation mediates species presence beyond their environmental optimum
}

O’Brien, Michael J ; de Menezes, Luis Fernando Tavares ; Bråthen, Kari Anne ; Losapio, Gianalberto ; Pugnaire, Francisco I

\begin{abstract}
Species distributions are driven by abiotic conditions that filter species with specific traits and physiological tolerances and match them with their suitable environment. Plant-plant interactions can constrict (through competition) or loosen (through facilitation) the strength of these environmental filters, which in turn inhibit or enhance establishment and recruitment of plant species at a finer spatial scale. Although competition is often the focus of community assembly processes that further impede the entry of plant species into a site, facilitation is also important for potentially loosening environmental filters (especially climatic filters such as temperature and precipitation), ultimately enhancing species occurrence beyond their physiological optimum. We used multiple data sets from the arid site of Rambla del Saltador Valley to test the hypothesis that facilitation by a nurse-plant promotes the presence of herbaceous, beneficiary species beyond their environmental optimum relative to open sites. Furthermore, we propose that the median elevation and community composition of herbaceous species expands with the age of the nurse-plant, and we tested this hypothesis by examining 105 beneficiary species under 50 nurse-plant shrubs varying in age from 6 to 48 years old. We found nurse-plants both facilitate herbaceous species occurrence beyond their median elevation and support more diverse and a distinctly different composition of species in contrast to open sites. Specifically, herbaceous species that originate from a median elevation more than 600 to $700 \mathrm{~m}$ above the site only existed beneath nurse-plants, and below this median elevation, half the species only occurred below the nurse-plant. Moreover, the richness and elevation provenance of the herbaceous species increased with increasing nurse-plant age. Our results highlight the importance of facilitation for alleviating physiological strain (in support of the strain hypothesis) and mediating regional species distributions, which has implications for understanding species movements and community assembly at larger-scales under hotter and drier climates.
\end{abstract}

DOI: https://doi.org/10.1016/j.ppees.2019.03.004

Posted at the Zurich Open Repository and Archive, University of Zurich

ZORA URL: https://doi.org/10.5167/uzh-216985

Journal Article

Accepted Version

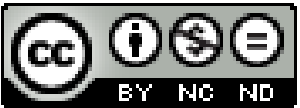

The following work is licensed under a Creative Commons: Attribution-NonCommercial-NoDerivatives 4.0 International (CC BY-NC-ND 4.0) License.

Originally published at:

O’Brien, Michael J; de Menezes, Luis Fernando Tavares; Bråthen, Kari Anne; Losapio, Gianalberto; Pugnaire, Francisco I (2019). Facilitation mediates species presence beyond their environmental optimum. Perspectives in 
Plant Ecology, Evolution and Systematics, 38:24-30.

DOI: https://doi.org/10.1016/j.ppees.2019.03.004 


\section{Accepted Manuscript}

Title: Facilitation mediates species presence beyond their environmental optimum

Authors: Michael J. O’Brien, Luis Fernando Tavares de Menezes, Kari Anne Bråthen, Gianalberto Losapio, Francisco

I. Pugnaire

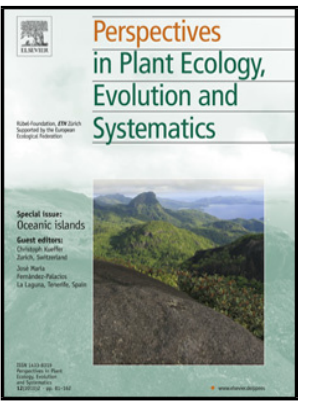

PII: S1433-8319(18)30099-4

DOI:

Reference: https://doi.org/10.1016/j.ppees.2019.03.004

To appear in:

Received date: $\quad 28$ June 2018

Revised date: $\quad 17$ January 2019

Accepted date: $\quad 24$ March 2019

Please cite this article as: O'Brien MJ, de Menezes LFT, Bråthen KA, Losapio G, Pugnaire FI, Facilitation mediates species presence beyond their environmental optimum, Perspectives in Plant Ecology, Evolution and Systematics (2019), https://doi.org/10.1016/j.ppees.2019.03.004

This is a PDF file of an unedited manuscript that has been accepted for publication. As a service to our customers we are providing this early version of the manuscript. The manuscript will undergo copyediting, typesetting, and review of the resulting proof before it is published in its final form. Please note that during the production process errors may be discovered which could affect the content, and all legal disclaimers that apply to the journal pertain. 
Facilitation mediates species presence beyond their environmental optimum

Michael J. O’Brien ${ }^{1 *}$, Luis Fernando Tavares de Menezes², Kari Anne Bråthen ${ }^{3}$, Gianalberto

Losapio $^{4}$, Francisco I. Pugnaire ${ }^{1^{*}}$

${ }^{1}$ Estación Experimental de Zonas Áridas, Consejo Superior de Investigaciones Científicas,

Carretera de Sacramento s/n, E-04120 La Cañada, Almería, Spain

${ }^{2}$ Universidade Federal do Espírito Santo, Centro Universitário Norte do Espírito Santo, BR 101

Norte, Km 60 - Bairro Litorâneo, São Mateus, 29.932-540, Espírito Santo, Brasil

${ }^{3}$ Department of Arctic and Marine Biology, UiT, The Arctic University of Norway, NO-9037

Troms $\phi$, Norway

${ }^{4}$ ETH Zurich, Biocommunication group, Schmelzbergstrasse 9, 8092, Zurich, Switzerland

*corresponding authors: mikey.j.obrien@gmail.com

Abstract: 300 words

Main text: 4327 words

3 Figures; 63 References

\section{Highlights:}

- Nurse plants promote beneficiary herbaceous species beyond their physiological optimum

- Older nurse plants support a greater diversity of plants from a larger elevation range than younger nurse plants

- Our results support the role of facilitation to reduce physiological strain

- Nurse plants promote the movement of species along elevation gradients

- Nurse plants are important for plant range shifts under climate change 


\begin{abstract}
Species distributions are driven by abiotic conditions that filter species with specific traits and physiological tolerances and match them with their suitable environment. Plant-plant interactions can constrict (through competition) or loosen (through facilitation) the strength of these environmental filters, which in turn inhibit or enhance establishment and recruitment of plant species at a finer spatial scale. Although competition is often the focus of community assembly processes that further impede the entry of plant species into a site, facilitation is also important for potentially loosening environmental filters (especially climatic filters such as temperature and precipitation), ultimately enhancing species occurrence beyond their physiological optimum. We used multiple data sets from the arid site of Rambla del Saltador Valley to test the hypothesis that facilitation by a nurse-plant promotes the presence of herbaceous, beneficiary species beyond their environmental optimum relative to open sites. Furthermore, we propose that the median elevation and community composition of herbaceous species expands with the age of the nurse-plant, and we tested this hypothesis by examining 105 beneficiary species under 50 nurse-plant shrubs varying in age from 6 to 48 years old. We found nurse-plants both facilitate herbaceous species occurrence beyond their median elevation and support more diverse and a distinctly different composition of species in contrast to open sites. Specifically, herbaceous species that originate from a median elevation more than 600 to $700 \mathrm{~m}$ above the site only existed beneath nurse-plants, and below this median elevation, half the species only occurred below the nurse-plant. Moreover, the richness and elevation provenance of the herbaceous species increased with increasing nurse-plant age. Our results highlight the
\end{abstract}


importance of facilitation for alleviating physiological strain (in support of the strain hypothesis) and mediating regional species distributions, which has implications for understanding species movements and community assembly at larger-scales under hotter and drier climates.

\section{Keywords}

Species distributions, climate change, community assembly, environmental filters, nurse-plants, plant-climate interactions

\section{Introduction}

Understanding the processes that underlie patterns of species distribution is a cornerstone of ecology (MacArthur, 1972; Whittaker and Niering, 1975), which is increasingly relevant for predicting community assembly in a changing climate (Alexander et al., 2016, 2015; Soliveres et al., 2015). Species diversity at any location is governed by large-scale biogeographic and evolutionary processes as well as by local biotic and abiotic mechanisms (Brooker et al., 2008; Cavieres et al., 2014; Harrison and Cornell, 2008; Ricklefs, 2008, 2004). Within the suite of plant-plant interactions, competitive exclusion can inhibit species occurrence (Alexander et al., 2015; Chesson, 2000; Hart and Marshall, 2013; Kraft et al., 2015; Schöb et al., 2013) while, in contrast, facilitation can increase the realized niche of plant species at local and regional scales by ameliorating environmental filters — such as climatic conditions across environmental gradients - thereby promoting species presence beyond their environmental optimum (Armas et al., 2011; Gross et al., 2010; Liancourt et al., 2017; Schöb et al., 2014a; Soliveres et al., 2015; Valiente-Banuet et al., 2006; Wisz et al., 2013). Assessing the influence of nurse-plants on regional-scale species distribution can help our understanding of species dynamics and community assembly under a changing environment (Bruno et al., 2003; Cavieres et al., 2016; Liancourt et al., 2017; O’Brien et al., 2017b; Pugnaire et al., 1996; Schöb et al., 2012). 
Facilitation is a widespread process particularly important for species coexistence in low resource or stressful climatic environments (Callaway, 2007; Filazzola and Lortie, 2014; Fugère et al., 2012; He et al., 2013). In plant communities, facilitation is often, but not solely, shown as the effect of a nurse-plant on beneficiary species whereby the nurse promotes the establishment, growth or reproduction of stress-sensitive species under their canopy (Bertness and Callaway, 1994). The relative importance of facilitation for the persistence of a species increases as the environmental conditions at a site diverge from the physiological optimum of the species - i.e. the more strain (termed the strain hypothesis) on a species at a site (Gross et al., 2010; Liancourt et al., 2017). In arid systems, this hypothesis would imply that facilitation is asymmetric with species from higher elevations (cooler and wetter sites) benefitting more from facilitation than species from lower elevations (hotter and drier sites) due to the greater physiological tolerance to arid conditions of lower elevation species and more physiological strain on higher elevation species (Liancourt et al., 2017). In other words, nurse species can expand niche space within suboptimal environments thereby allowing species to exist in locations beyond their environmental optimum (Wiens, 2011). This process can in turn increase local community diversity and productivity, which mediates geographic distributions at larger scales (Bulleri et al., 2016; Cavieres et al., 2014; Ettinger and HilleRisLambers, 2017; Kraft et al., 2015; Schöb et al., 2012).

Common mechanisms underpinning facilitation are amelioration of microclimate conditions and improvement of understory soil properties, and as nurse-plants grow older, the complexity and heterogeneity of soil and climatic conditions will increase (Lozano et al., 2017; Pugnaire et al., 2011, 1996). This correlation between the complexity of the understorey niche and nurse-plant age suggests that older nurse-plants will support more beneficiary species by providing niche space to a larger breadth of physiological optimum. Pugnaire et al., (1996) found 
older and larger nurse-plants host more than twice the number of beneficiary species than younger nurse-plants. This was mainly attributed to the increase of organic matter, $\mathrm{N}$ and $\mathrm{P}$ availability and water availability with increasing nurse-plant age (Pugnaire et al., 2011, 1996). Although such increases in resource availability with nurse-plant age may enhance competition in the understory, the facilitation effects of the nurse often overshadow negative interactions among beneficiary species (Pugnaire et al., 1996; Schöb et al., 2013).

Climatic conditions in many ecosystems are becoming hotter and drier (O’Brien et al., 2017a), and for plant species to avoid extinction (either local, regional or global) under novel climatic regimes, they will need to either change their distributions to track their current climatic conditions or persist under novel climatic conditions in their current distributions (Alexander et al., 2015; Ettinger and HilleRisLambers, 2017). For example, in alpine systems, climate change is increasing temperatures across the elevation gradient, and plant species will need to either move upward in elevation to avoid warming or persist under warmer conditions at their current elevation (Alexander et al., 2015; Valiente-Banuet et al., 2006). In arid systems such as the Mediterranean, temperatures decrease but precipitation increases with increasing elevation (Liancourt et al., 2017; Schöb et al., 2014b), so that hotter, drier conditions are moving up in elevation under climate change (Scherrer and Körner, 2010). Nurse-plants may buffer species from warmer and drier conditions thereby providing refugia from the changing climate (O'Brien et al., 2017b). The presence of beneficiary species at lower and more arid elevations beyond their preferred environment would indicate the buffering ability of nurse-plants in novel climatic conditions, and as nurse-plants age and grow larger, they may be able to buffer a greater quantity and diversity of beneficiary species. Particularly, the more beneficiary species deviate from their physiological optimum the greater the importance of nurse-plants for mediating higher diversity. 
We propose a concept whereby nurse-plants alleviate environmental conditions (i.e. reduce physiological strain) at an arid site (Fig. 1) that allows species occurrence far from their environmental optimum (i.e. median elevation). Using the model nurse-plant, Retama sphaerocarpa (Retama; Pugnaire et al., 1996), we tested the hypothesis that the diversity and breadth of median elevation of the beneficiary species increases with Retama age. We posit that older nurse-plants support species far from their median elevation due to a greater complexity of microsites and accumulation of resources beneath them. We expect that species originating from higher elevations and cooler and wetter climates can occur in lower and more arid elevations due to facilitation, while the relative importance of facilitation will be weaker on species moving from more arid elevations.

\section{Materials and Methods}

\section{Field site and data collection}

All species occurrence data were collected from the Rambla del Saltador valley in the Almeria province, Southeast Spain ( $37^{\circ} 07^{\prime} 43^{\prime \prime} \mathrm{N}, 2^{\circ} 22^{\prime} 13^{\prime \prime} \mathrm{W} ; 630 \mathrm{~m}$ elevation). The site is arid with a dry season from May to September and a wetter season from December to March (Puigdefábregas et al., 1996). The average rainfall is $256 \mathrm{~mm}$ per year with irregular intra- and inter-annual distribution. The valley is alluvial detritus with low water holding capacity, organic matter and nutrient concentrations. It is dominated by randomly and sparsely distributed Retama sphaerocarpa (Retama) individuals from the Fabaceae family, a leafless leguminous shrub with a deep root system which performs hydraulic lift (Prieto et al., 2011). Other vascular plants are concentrated around Retama with sparse vegetation between shrubs dominated by drought tolerant plants (Pugnaire et al., 1996), especially in low rainfall years where few plants occur in open sites (O'Brien et al., 2017b). Retama shrubs improve their understorey environment by 
increasing soil water content and soil organic matter and nutrients (Pugnaire et al., 1996). Shrub canopies also buffer solar radiation reaching the soil up to $\sim 40 \%$, leading to a decrease in mean daily temperatures of up to $3^{\circ} \mathrm{C}$ compared to gaps and $7^{\circ} \mathrm{C}$ in max temperature (Moro et al., 1997b). Combined, microclimate conditions and litter accumulation under the canopy produce a number of strong gradients -often opposing each other (Moro et al., 1997a), that increase niche availability (Michalet et al., 2015; O'Brien et al., 2017b) and allow for the establishment of a great diversity of plant species. The positive effects of Retama on understorey productivity and diversity has been widely shown in previous studies (Michalet et al., 2015; Moro et al., 1997b; O’Brien et al., 2017b; Prieto et al., 2010; Pugnaire et al., 1996; Pugnaire and Luque, 2001), although the facilitative effects of Retama decrease with increasing elevation (Pugnaire and Luque, 2001).

Two data sets were used for this analysis. The first dataset was from Pugnaire and Lázaro (2000) which includes the herbaceous beneficiary species under 50 Retama shrubs that ranged from 6 to 48 years of age (measured from destructive harvests and ring counts) and with crown areas ranging from 0.4 to $44 \mathrm{~m}^{2}$ (estimated allometrically from length and width). The second dataset was compiled from a number of experiments that were carried out at the same field site over multiple years (Armas et al., 2011; Hortal et al., 2015; O’Brien et al., 2017b; Schöb et al., 2013). These data were of herbaceous plants collected in open spaces between Retama in sampled areas ranging from 0.2 to $11.3 \mathrm{~m}^{2}$ (total sample area of $12.6 \mathrm{~m}^{2}$ ) and provided an open site contrast to the herbaceous community under Retama.

Elevation ranges of beneficiary species were compiled from Blanca et al., (2009). We used the median elevation of the recorded range of each species (i.e. median point of the lower and upper limits) as the unit to define their optimal elevation. Using median elevation is a robust 
measure of central tendency of species distribution but limits between-species comparison as it ignores the shape (i.e. assumes normal distribution) and width of the distribution such that two species with a median elevation of $500 \mathrm{~m}$ are assumed the same even though one could exist from 400 to $600 \mathrm{~m}$ and the other from 200 to $800 \mathrm{~m}$. However, our goal was to assess the level of deviation between our study site elevation and the optimal elevation for each species rather than specifically contrasting the differences among species. For practical reasons, we assumed that the median elevation $\pm 200 \mathrm{~m}$ from the elevation of the site were native to the site (Scherrer and Körner, 2010). Based on these assumptions, species were assigned to three elevation categories: 1) less than 430 masl (low elevation compared to our study site), 2) $430-830$ masl (home elevation of our study site) and 3) greater than 830 masl (high elevation compared to our study site). We tested the importance of this categorization by altering the cut-off of elevations for these three levels and found that our results were qualitatively robust regardless of the width of the category examined (see Figure S1 and S2 in Appendix).

\section{Statistical analysis}

To assess the importance of Retama for species richness of plants originating from different median elevations, we calculated the ratio of the number of species present only under Retama from a median elevation versus the total number of species from that median elevation present under Retama and in open sites. Therefore, if all species from a median elevation were only found under Retama, the ratio would be one, and if all species were only found in open sites, the ratio would be zero. We calculated this ratio at $100 \mathrm{~m}$ increments from greater than $1000 \mathrm{~m}$ difference downward (species with a median elevation above $1630 \mathrm{~m}$ ) to greater than $500 \mathrm{~m}$ difference upward (species with a median elevation of less than $130 \mathrm{~m}$ ). We used a simple loess smoother to show the trend across the change in elevation. 
To test for differences in composition between Retama and open site, we calculated the dissimilarities in the herbaceous community compositions using the Jaccard index based on species presence-absence per plot. We performed constrained analysis of proximities on the Jaccard distance matrix to test the effect of the constraining terms site (a fixed factor with 2 levels; Retama and open) and age (a continuous variable; open were considered zero). We tested the significance of the constraining terms with a permutation test. If the inertia in the permuted models was lower than in the constrained model, then the association was considered statistically significant. These analyses were done with R statistical software (version 3.3.2; http://rproject.org). The vegdist function in the vegan package (Oksanen et al., 2015) was used to calculate Jaccard dissimilarities. The constrained analysis of proximities was performed with the capscale function (Legendre and Anderson, 1999), and the permutation test was done with the anova function in the vegan package.

Species richness was analysed as a function of Retama age (a continuous variable), origin elevation of the species (a fixed factor with 3 levels; low, home and high elevation) and their interaction using a generalized-linear mixed model with a Poisson distribution and a log link function (see ANOVA Table S1 of Wald statistics in the Appendix). We included a random effect for Retama plant (a random term with 50 levels, the number of individual shrubs assessed). We included a covariate for Retama canopy area to control for the effects of plant size.

To estimate the significance of the observed species richness across the age gradient, we used a null model approach. Random communities were assigned according to a probabilistic null model that builds communities from the community matrix considering the probability of species presence-absence among Retama shrubs (Bascompte et al., 2003). In particular, the community matrix ( $M=$ Retama $\times$ Species $)$ indicates the presence or absence of a beneficiary 
species $j$ beneath a Retama $i$. For each Retama-species pair, the probability that a species $j$ occurs beneath a Retama $i$ is drawn from a binomial distribution with density $d=\frac{1}{2}\left(\frac{a_{\text {Species }}}{\text { Retama }}+\frac{a_{\text {Retama }}}{\text { Species }}\right)$

where $a_{\text {Species }}$ is the number of Retama a beneficiary species $j$ is occurring beneath, $a_{\text {Retama }}$ is the number of beneficiary species occurring beneath a Retama $i$, 'Retama' is the total number of Retama and open plot, 'Species' is the total number of beneficiary species. Thus, the occurrence probability of a beneficiary species beneath Retama depends on both the distribution of each beneficiary species among Retama shrubs and on the capability of each Retama of hosting beneficiary species. To test whether the observed species richness was significantly different from the probabilistic null model, we calculated species richness from 1000 probabilistic communities and used linear mixed-effects model of richness as a function of area sampled and age (see ANOVA Table S2 of Wald statistics in Appendix). This analysis was performed separately for the community of beneficiary species from low, home and high elevation. We also assessed the standardized effect size with a z-score, which was calculated as the difference between the observed richness and mean simulated richness under a Retama divided by the standard deviation of the simulated richness. We analyzed this as a function of Retama age in a linear model separately for the community of beneficiary species from low, home and high elevation (see ANOVA Table S3 of Wald statistics in Appendix). The mixed effects models were performed with the asreml-R package (ASReml 3, VSN International, UK) in the R statistical software (version 3.3.2; http://r-project.org).

\section{Results}


After examining species distributions based on the most up-to-date taxonomy and floristic data (Blanca et al., 2009), a total of 105 species were identified in our Retama dataset (see Table S4 for full species list in Appendix), and one species, Polycarpon tetraphyllum, was removed from analysis due to the uncertainty of the subspecies. Of the 104 species analysed, 60 species ( $\sim 58 \%$ of the total) had their median elevation within $200 \mathrm{~m}$ of the elevation of the site (home origin; Fig. 2a). Of the remaining species, Retama provided habitat for 11 species ( 11\%) with a lower median elevation, and 33 species (32\%) species with a higher median elevation (Fig. 2a). In open site data, 61 species were identified (see Table S4 for full species list) with 35 species (57\%) from the home origin while 9 species (15\%) were from a lower elevation and 17 species $(28 \%)$ were from a higher elevation.

The range of species found in open plots was much narrower with species originating from $200-1200 \mathrm{~m}$ in the open versus $200-1850 \mathrm{~m}$ under Retama. Therefore, the range of median elevations of species at the study site was more than 1.5 times larger with facilitation by Retama than without. In support of our hypothesis, moving up in elevation was less common Silene littorea was the lowest species found with a distribution between 0 and $400 \mathrm{~m}$ - although there is a lower elevation limit of $0 \mathrm{~m}$ as species are not moving up from below sea-level. Alternatively, species moved down in elevation as much as $1220 \mathrm{~m}$ (e.g. Alyssum granatense found at an elevation range of $1600-2100$ masl), and the community under Retama had twice as many species from higher elevations than open sites. Furthermore, $100 \%$ of the species originating from a median elevation above $1300 \mathrm{~m}$ were only found under Retama (Fig. 2b) as no species from the high elevations occurred in open sites. Below this elevation, $50 \%$ of the species on average from all other median elevations were found solely under Retama. This resulted in Retama hosting a distinctly different community than that found in open sites $(\mathrm{P}<$ 
0.001), and beneficiary community composition under older Retama was significantly different from younger Retama communities $(\mathrm{P}<0.001$; Fig $2 \mathrm{c})$. The results in figure two were robust if the largest shrubs $\left(>12 \mathrm{~m}^{2}\right)$ were removed from the analysis to control for differences in sampling area between open and Retama plots (Figure S3 in Appendix).

Overall species richness increased with increasing Retama age regardless of median elevation origin (Fig. 3a). Species richness under the youngest Retama shrubs (6 years old) was highest for beneficiary species originating from the home site ( 12.0 species, $95 \%$ CI: 10.1 14.3), lowest for species from low elevations ( 2.8 species, $95 \%$ CI: $2.1-3.6)$ and intermediate from the high elevations (6.4 species, 95\% CI: 5.2 - 7.8). After controlling for Retama canopy area, species richness significantly increased with Retama age for the home and high elevation groupings but not for the species from the low elevation (Fig. 3b-d). The increase in species richness was greatest for home elevation species (slope of age on log scale $=0.03,95 \%$ CI: 0.01 -0.04 ) followed by high elevation species (slope of age on log scale $=0.02,95 \%$ CI: $0.0004-$ 0.03) while the richness of low elevation species was similar across all Retama ages (slope of age on log scale $=0.01,95 \% \mathrm{CI}:-0.01-0.03)$. Therefore, home elevation species richness increased by $\sim 15$ species from 6-year-old Retama to 27-year-old Retama while low elevation species richness increased by $\sim 1$ species and high elevation species richness increased by $\sim 3$ species across the same Retama age range. This resulted in a near doubling of species richness between younger and older Retama. Our analysis compared to a probabilistic null model confirmed these results as the difference between the observed and null community increased with increasing Retama age (see Figure S4 in Appendix). The standardized z-scores also significantly increased with Retama age.

\section{Discussion}


Our combined analyses of beneficiary species under and outside canopies of nurse-plants shows that nurse-plants support species from a larger median elevation breadth, and the relative importance of facilitation increases as the median elevation of the beneficiary species increases. These results provide direct evidence in support of reduced physiological strain hypothesis (Gross et al., 2010). However, nurse-plants also supported distinctly different species than the open sites even for beneficiary species that originated from a similar median elevation as the site, suggesting facilitation also functions to support species unable to survive in open areas. These processes led to a distinct community composition under Retama relative to open sites, confirming that facilitation is an important process affecting community assembly and diversity (Brooker et al., 2008; Tirado and Pugnaire, 2005). Specifically, these results highlight that the importance of facilitation increases with increasing differences between beneficiary-species average habitat and nurse-plant habitat. In addition, our results from multiple analyses indicate that older Retama plants support nearly twice as many species and from a larger breadth of median elevation than younger Retama plants.

Mechanisms of facilitation for reducing physiological strain are due to effects of facilitator shrubs on climatic conditions under their canopy (Pugnaire et al., 1996) with fundamental consequences for relaxing environmental filters associated with elevation gradients in arid ecosystems (Moro et al., 1997b). Therefore, nurse-plants in arid environments provide refugia from high temperatures and low availability of resources, particularly water and nutrients (Pugnaire et al., 2011), which allowed the presence of beneficiary species far from their optimal environmental conditions, especially species from higher elevations (wetter and cooler sites). These results have implications for the distribution of species due to changing climates because it suggests that plant-plant interactions can supersede climatic filters that limit species 
establishment and survival, and in turn may allow species to either persist in altered climates or more effectively track shifting climatic conditions. Models forecasting the presence of species (i.e. distributions) under climate change should therefore consider the effects of nurse-plant refugia.

Our results show that plant-plant interactions at the local-scale influence meso-scale diversity patterns, which directly supports the results of Cavieres et al., (2014) that showed similar processes shape diversity in alpine ecosystems worldwide. Species distributions are often defined by bioclimatic envelopes (Elith and Leathwick, 2009; Sexton et al., 2009), since climate variables are primary determinants of the species richness and composition of vascular plant communities (Marini et al., 2008; Moser et al., 2005). However, the presence of favourable habitats (including microhabitats under facilitator species) may have higher predictive power at smaller spatial resolutions. Indeed, our study indicates not only that the structure of plant communities is driven by local biotic interactions but also that local plant-plant interactions can shape the large-scale distribution of species. These results imply that macroecological patterns may result from microecological processes (Wisz et al., 2013). Even though the data from open locations also supported some species originating from higher and lower elevations, the overall distribution of the median elevation of species was smaller, and no species from above $1300 \mathrm{~m}$ were found in open sites. This smaller range was found despite the fact that the open data came from multiple years and also included the 2009 to 2010 year, which had significantly higher than average rainfall (O'Brien et al., 2017b). These multiple years of sampling and high rainfall years likely inflated the species richness found in open sites. Our analysis of species composition further supported the importance of Retama presence and age for harbouring unique beneficiary species unable to persist outside the Retama canopy. Therefore, facilitation relaxed climatic 
filters on plant diversity that restricted establishment and recruitment of species from other environments while also supporting species originating locally that are unable to exist outside the nurse-plant canopy (Armas et al., 2011; O’Brien et al., 2017b; Schöb et al., 2013).

In support of our prediction, more species from higher elevations than from lower elevations benefitted from facilitation. A primary component of facilitation in these arid sites is reduced temperatures from increased shading and hydraulic lift from deeply rooted nurse-plants (Butterfield et al., 2010; López-Pintor et al., 2006; Moro et al., 1997b), which would create environmental conditions more suitable to plants originating from cooler and wetter sites at higher elevations than from warmer and drier sites at lower elevations. This result supports the strain hypothesis (Gross et al., 2010; Liancourt et al., 2017). The elevation in this arid system is associated with temperature and precipitation patterns that influence plant growth and lead to changes in species composition and physiognomy of plant communities over large environmental gradients (Austin, 1987; Körner, 2007; Pendry and Proctor, 1997; Proctor et al., 1988), but Retama sustained species that originated from sites as much as $1200 \mathrm{~m}$ above the study site. Therefore, Retama substantially relaxed environmental constraints, which may ultimately result in higher species diversity. Dispersal is also a likely secondary component of the greater number of species from high elevation at the site because it is easier to disperse downslope via wind and water than upslope (Thompson and Katul, 2009; Venable et al., 2008). Therefore, introduction rates of species from higher elevations would be greater than that of species from lower elevations. There was a constraint on the median elevation limit of lower elevation species (i.e. species were limited to $630 \mathrm{~m}$ below the site due to sea-level), but the results show the proportion of species richness that depended on facilitation was decreasing with decreasing median elevation. 
Not surprisingly, most species were from the same environmental belt as the field site (Thermomediterranean semiarid; Lázaro et al., 2001). However, the herbaceous communities were comprised of many species found in wetter environments. For example, Armas et al., (2011) reported 10 species from this site that are distributed across a gradient from 250 to 2000 $\mathrm{mm}$ of annual rainfall (4-fold change in mean annual precipitation). Therefore, it is important to note that the elevation gradient is an indicator of both a temperature and precipitation gradient, and facilitation at the site is also contributing to the distribution of species across latitudinal and longitudinal precipitation gradients.

Temperatures are increasing in many terrestrial systems around the globe, and plants will either need to track the current climate associated with their home elevation range or persist in novel climates (Alexander et al., 2016). In addition to warming, precipitation is also changing worldwide, and many places are already facing reductions in precipitation and more variable rainfall patterns (O'Brien et al., 2017a). Our results suggest that plants are already moving in the attempt to find suitable microhabitats to escape these climatic stresses. Facilitation may support biodiversity by providing refugia for plants to persist under hotter and drier conditions at their native sites (O'Brien et al., 2017b) as well as mediate the movement of species tracking climatic conditions. Recent work from Ettinger and HilleRisLambers (2017) showed that interactions between juvenile and adult trees were facilitative at the upper elevation limits, which improved establishment of juveniles. Therefore, it is important to consider facilitation as a factor promoting community assembly as climate change drives interactions among novel species neighbours (Alexander et al., 2015).

Our analysis highlights the importance of facilitation for reducing physiological strain for species outside of their climatic optimum while also maintaining local species sensitive to arid 
conditions. Both processes promote large-scale species distributions along elevational gradients in arid systems (i.e. gradients of temperature and moisture). These results suggest that the influence of older nurse-plants on micro-environmental conditions is especially important for the presence of species far from their physiological optimum.

\section{Acknowledgements}

This work was funded by AEI (çCGL2017-84515-R). MOB was supported by the Swiss

National Science Foundation through an Advanced Postdoc Mobility Fellowship (P300PA_167758).

\section{Author contributions}

FIP conceived the experiment, provided community data and contributed to data compilation. MOB analyzed the data and wrote the manuscript. LFT compiled the data. KAB contributed to data compiling and provided an initial version of the manuscript. GL performed the null model testing. All authors contributed to revisions.

\section{References}

Alexander, J.M., Diez, J.M., Hart, S.P., Levine, J.M., 2016. When climate reshuffles competitors: A call for experimental macroecology. Trends Ecol. Evol. 31, 831-841. https://doi.org/10.1016/j.tree.2016.08.003

Alexander, J.M., Diez, J.M., Levine, J.M., 2015. Novel competitors shape species' responses to climate change. Nature 525, 515-518. https://doi.org/10.1038/nature14952

Armas, C., Rodríguez-Echeverría, S., Pugnaire, F.I., 2011. A field test of the stress-gradient hypothesis along an aridity gradient. J. Veg. Sci. 22, 818-827. https://doi.org/10.1111/j.1654-1103.2011.01301.x 
Austin, M.P., 1987. Models for the analysis of species' response to environmental gradients. Vegetatio 69, 35-45. https://doi.org/10.1007/BF00038685

Bascompte, J., Jordano, P., Melian, C.J., Olesen, J.M., 2003. The nested assembly of plantanimal mutualistic networks. Proc. Natl. Acad. Sci. 100, 9383-9387. https://doi.org/10.1073/pnas.1633576100

Bertness, M.D., Callaway, R., 1994. Positive interactions in communities. Trends Ecol. Evol. 9, 187-191. https://doi.org/10.1016/0169-5347(94)90087-6

Blanca, G., Cabezudo, B., Cueto, M., Fernández López, C., Morales Torres, C., 2009. Flora Vascular de Andalucía Oriental. Consejería de Medio Ambiente, Junta de Andalucía, Sevilla.

Brooker, R.W., Maestre, F.T., Callaway, R.M., Lortie, C.L., Cavieres, L.A., Kunstler, G., Liancourt, P., Tielb??rger, K., Travis, J.M.J., Anthelme, F., Armas, C., Coll, L., Corcket, E., Delzon, S., Forey, E., Kikvidze, Z., Olofsson, J., Pugnaire, F., Quiroz, C.L., Saccone, P., Schiffers, K., Seifan, M., Touzard, B., Michalet, R., 2008. Facilitation in plant communities: The past, the present, and the future. J. Ecol. 96, 18-34. https://doi.org/10.1111/j.1365-2745.2007.01295.x

Bruno, J.F., Stachowicz, J.J., Bertness, M.D., 2003. Inclusion of facilitation into ecological theory. Trends Ecol. Evol. 18, 119-125. https://doi.org/10.1016/S0169-5347(02)00045-9

Bulleri, F., Bruno, J.F., Silliman, B.R., Stachowicz, J.J., 2016. Facilitation and the niche: Implications for coexistence, range shifts and ecosystem functioning. Funct. Ecol. 30, 7078. https://doi.org/10.1111/1365-2435.12528

Butterfield, B.J., Betancourt, J.L., Turner, R.M., Briggs, J.M., 2010. Facilitation drives 65 years 
of vegetation change in the Sonoran desert. Ecology 91, 1132-1139.

https://doi.org/10.1890/09-0145.1

Callaway, R.M., 2007. Interaction between competition and facilitation, in: Positive Interactions and Interdependence in Plant Communities. pp. 179-254.

Cavieres, L.A., Brooker, R.W., Butterfield, B.J., Cook, B.J., Kikvidze, Z., Lortie, C.J., Michalet, R., Pugnaire, F.I., Schöb, C., Xiao, S., Anthelme, F., Bjork, R.G., Dickinson, K.J.M., Cranston, B.H., Gavilán, R., Gutiérrez-Girón, A., Kanka, R., Maalouf, J.P., Mark, A.F., Noroozi, J., Parajuli, R., Phoenix, G.K., Reid, A.M., Ridenour, W.M., Rixen, C., Wipf, S., Zhao, L., Escudero, A., Zaitchik, B.F., Lingua, E., Aschehoug, E.T., Callaway, R.M., 2014. Facilitative plant interactions and climate simultaneously drive alpine plant diversity. Ecol. Lett. 17, 193-202. https://doi.org/10.1111/ele.12217

Cavieres, L.A., Hernández-Fuentes, C., Sierra-Almeida, A., Kikvidze, Z., 2016. Facilitation among plants as an insurance policy for diversity in Alpine communities. Funct. Ecol. 30, 52-59. https://doi.org/10.1111/1365-2435.12545

Chesson, P., 2000. Mechanisms of maintenance of species diversity. Annu. Rev. Ecol. Syst. 31, 343-366.

Elith, J., Leathwick, J.R., 2009. Species Distribution Models: Ecological Explanation and Prediction Across Space and Time. Annu. Rev. Ecol. Evol. Syst. 40, 677-697. https://doi.org/10.1146/annurev.ecolsys.110308.120159

Ettinger, A., HilleRisLambers, J., 2017. Competition and facilitation may lead to asymmetric range shift dynamics with climate change. Glob. Chang. Biol. 23, 3921-3933. https://doi.org/10.1111/gcb.13649 
Filazzola, A., Lortie, C.J., 2014. A systematic review and conceptual framework for the mechanistic pathways of nurse plants. Glob. Ecol. Biogeogr. 23, 1335-1345. https://doi.org/10.1111/geb.12202

Fugère, V., Andino, P., Espinosa, R., Anthelme, F., Jacobsen, D., Dangles, O., 2012. Testing the stress-gradient hypothesis with aquatic detritivorous invertebrates: Insights for biodiversityecosystem functioning research. J. Anim. Ecol. 81, 1259-1267. https://doi.org/10.1111/j.1365-2656.2012.01994.x

Gross, N., Liancourt, P., Choler, P., Suding, K.N., Lavorel, S., 2010. Strain and vegetation effects on local limiting resources explain the outcomes of biotic interactions. Perspect. Plant Ecol. Evol. Syst. 12, 9-19. https://doi.org/10.1016/j.ppees.2009.09.001

Harrison, S., Cornell, H., 2008. Toward a better understanding of the regional causes of local community richness. Ecol. Lett. 11, 969-979. https://doi.org/10.1111/j.14610248.2008.01210.x

Hart, S.P., Marshall, D.J., 2013. Environmental stress, facilitation, competition, and coexistence. Ecology 94, 2719-2731.

He, Q., Bertness, M.D., Altieri, A.H., 2013. Global shifts towards positive species interactions with increasing environmental stress. Ecol. Lett. 16, 695-706. https://doi.org/10.1111/ele.12080

Hortal, S., Bastida, F., Moreno, J.L., Armas, C., García, C., Pugnaire, F.I., 2015. Benefactor and allelopathic shrub species have different effects on the soil microbial community along an environmental severity gradient. Soil Biol. Biochem. 88, 48-57. https://doi.org/10.1016/j.soilbio.2015.05.009 
Körner, C., 2007. The use of "altitude" in ecological research. Trends Ecol. Evol. 22, 569-574. https://doi.org/10.1016/j.tree.2007.09.006

Kraft, N.J.B., Adler, P.B., Godoy, O., James, E.C., Fuller, S., Levine, J.M., 2015. Community assembly, coexistence and the environmental filtering metaphor. Funct. Ecol. 29, 592-599. https://doi.org/10.1111/1365-2435.12345

Lázaro, R., Rodrigo, F.S.S., Gutiérrez, L., Domingo, F., Puigdefábregas, J., 2001. Analysis of a 30-year rainfall record (1967-1997) in semi-arid SE spain for implications on vegetation. J. Arid Environ. 48, 373-395. https://doi.org/10.1006/jare.2000.0755

Legendre, P., Anderson, M.J., 1999. Distace-based redundancy analysis: Testing multispecies responses in multifactorial experiments. Ecol. Monogr. 69, 1-24. https://doi.org/10.1890/0012-9615(1999)069[0001:DBRATM]2.0.CO;2

Liancourt, P., Le Bagousse-Pinguet, Y., Rixen, C., Dolezal, J., 2017. SGH: Stress or strain gradient hypothesis? Insights from an elevation gradient on the roof of the world. Ann. Bot. 120, 29-38. https://doi.org/10.1093/aob/mcx037

López-Pintor, A., Gómez Sal, A., Rey Benayas, J.M., 2006. Shrubs as a source of spatial heterogeneity - the case of Retama sphaerocarpa in Mediterranean pastures of central Spain. Acta Oecologica 29, 247-255. https://doi.org/10.1016/j.actao.2005.11.001

Lozano, Y.M., Armas, C., Hortal, S., Casanoves, F., Pugnaire, F.I., 2017. Disentangling aboveand below-ground facilitation drivers in arid environments: the role of soil microorganisms, soil properties and microhabitat. New Phytol. 216, 1236-1246. https://doi.org/10.1111/nph.14499

MacArthur, R.H., 1972. Geographical Ecology: Patterns in the Distribution of Species. Princeton 


\section{University Press.}

Marini, L., Scotton, M., Klimek, S., Pecile, A., 2008. Patterns of plant species richness in Alpine hay meadows: Local vs. landscape controls. Basic Appl. Ecol. 9, 365-372. https://doi.org/10.1016/j.baae.2007.06.011

Michalet, R., Brooker, R.W., Lortie, C.J., Maalouf, J.P., Pugnaire, F.I., 2015. Disentangling direct and indirect effects of a legume shrub on its understorey community. Oikos 124, 1251-1262. https://doi.org/10.1111/oik.01819

Moro, M., Pugnaire, F.I., Haase, P., Puigdefábregas, J., 1997a. Mechanisms of interaction between a leguminous shrub and its understorey in a semi- arid environment. Ecography (Cop.). 20, 175-184.

Moro, M., Puignaire, F.I., Haase, P., Puigdefábregas, J., 1997b. Effect of the canopy of Retama sphaerocarpa on its understorey in a semiarid environment. Funct. Ecol. 11, 425-431. https://doi.org/10.1046/j.1365-2435.1997.00106.x

Moser, D., Dullinger, S., Englisch, T., Niklfeld, H., Plutzar, C., Sauberer, N., Zechmeister, H.G., Grabherr, G., 2005. Environmental determinants of vascular plant species richness in the Austrian Alps. J. Biogeogr. 32, 1117-1127. https://doi.org/10.1111/j.13652699.2005.01265.x

O’Brien, M.J., Engelbrecht, B., Joswig, J., Pereyra, G., Schuldt, B., Jansen, S., Kattge, J., Landhäusser, S., Levick, S., Preisler, Y., Väänänen, P., Macinnis-Ng, C., 2017a. A synthesis of tree functional traits related to drought-induced mortality in forests across climatic zones. J. Appl. Ecol. 54, 1669-1686. https://doi.org/10.1111/1365-2664.12874

O’Brien, M.J., Pugnaire, F.I., Armas, C., Rodríguez-Echeverría, S., Schöb, C., 2017b. The shift 
from plant-plant facilitation to competition under severe water deficit is spatially explicit. Ecol. Evol. 7, 2441-2448. https://doi.org/10.1002/ece3.2875

Oksanen, J., Blanchet, F., Kindt, R., Legendre, P., Minchin, P., O'Hara, R., Simpson, G., Solymos, P., Stevens, M., Wagner, H., 2015. vegan: Community Ecology Package. Pendry, C.A., Proctor, J., 1997. Altitudinal zonation of rain forest on Bukit Belalong, Brunei: Soils, forest structure and floristics. J. Trop. Ecol. 13, 221-241.

Prieto, I., Kikvidze, Z., Pugnaire, F.I., 2010. Hydraulic lift: Soil processes and transpiration in the Mediterranean leguminous shrub Retama sphaerocarpa (L.) Boiss. Plant Soil 329, $447-$ 456. https://doi.org/10.1007/s11104-009-0170-3

Prieto, I., Padilla, F.M., Armas, C., Pugnaire, F.I., 2011. The role of hydraulic lift on seedling establishment under a nurse plant species in a semi-arid environment. Perspect. Plant Ecol. Evol. Syst. 13, 181-187. https://doi.org/10.1016/j.ppees.2011.05.002

Proctor, J., Lee, Y.F., Langley, A.M., Munro, W.R.C., Nelson, T., 1988. Ecological studies on Gunung Silam, a small ultrabasic mountain in Sabah, Malaysia. I. environment, forest structure and floristics. J. Ecol. 76, 320-340. https://doi.org/10.2307/2260596

Pugnaire, F.I., Armas, C., Maestre, F.T., 2011. Positive plant interactions in the Iberian Southeast: Mechanisms, environmental gradients, and ecosystem function. J. Arid Environ. 75, 1310-1320. https://doi.org/10.1016/j.jaridenv.2011.01.016

Pugnaire, F.I., Haase, P., Puigdefábregas, J., Cueto, M., Clark, S.C., Incoll, L.D., 1996. Facilitation and succession under the canopy of a leguminous shrub, Retama sphaerocarpa, in a semi-arid environment in south-east Spain. Oikos 76, 455-464. https://doi.org/10.2307/3546339 
Pugnaire, F.I., Lázaro, R., 2000. Seed bank and understorey species composition in a semi-arid environment: The effect of shrub age and rainfall. Ann. Bot. 86, 807-813. https://doi.org/10.1006/anbo.2000.1240

Pugnaire, F.I., Luque, M.T., 2001. Changes in plant interactions along a gradient of environmental stress. Oikos 93, 42-49.

Puigdefábregas, J., Alonso, J.M., Delgado, L., Domingo, F., Cueto, M., Gutiérrez, L., Lázaro, R., Nicolau, J.M., Sánchez, G., Solé, A., Vidal, S., Aguilera, C., Brenner, A., Clark, S., Incoll, L., 1996. The Rambla Honda filed site: Interactions of soil and vegetation along a catena in semi-arid Southeast Spain, in: Mediterranean Desertification and Land Use. pp. 137-168.

Ricklefs, R.E., 2008. Disintegration of the ecological community. Am. Nat. 172, 741-750. https://doi.org/10.1086/593002

Ricklefs, R.E., 2004. A comprehensive framework for global patterns in biodiversity. Ecol. Lett. 7, 1-15. https://doi.org/10.1046/j.1461-0248.2003.00554.x

Scherrer, D., Körner, C., 2010. Infra-red thermometry of alpine landscapes challenges climatic warming projections. Glob. Chang. Biol. 16, 2602-2613. https://doi.org/10.1111/j.13652486.2009.02122.x

Schöb, C., Armas, C., Pugnaire, F.I., 2013. Direct and indirect interactions co-determine species composition in nurse plant systems. Oikos 122, 1371-1379. https://doi.org/10.1111/j.16000706.2013.00390.x

Schöb, C., Butterfield, B.J., Pugnaire, F.I., 2012. Foundation species influence trait-based community assembly. New Phytol. 196, 824-834. https://doi.org/10.1111/j.14698137.2012.04306.x 
Schöb, C., Callaway, R.M., Anthelme, F., Brooker, R.W., Cavieres, L.A., Kikvidze, Z., Lortie, C.J., Michalet, R., Pugnaire, F.I., Xiao, S., Cranston, B.H., García, M.C., Hupp, N.R., Llambí, L.D., Lingua, E., Reid, A.M., Zhao, L., Butterfield, B.J., 2014a. The context dependence of beneficiary feedback effects on benefactors in plant facilitation. J. Physiol. 204, 386-396. https://doi.org/10.1111/nph.12908

Schöb, C., Prieto, I., Armas, C., Pugnaire, F.I., 2014b. Consequences of facilitation: One plant's benefit is another plant's cost. Funct. Ecol. 28, 500-508. https://doi.org/10.1111/13652435.12185

Sexton, J.P., Mcintyre, P.J., Angert, A.L., Rice, K.J., 2009. Evolution and ecology of species range limits. Annu. Rev. Ecol. Syst. 40, 415-436. https://doi.org/10.1146/annurev.ecolsys.110308.120317

Soliveres, S., Smit, C., Maestre, F.T., 2015. Moving forward on facilitation research: response to changing environments and effects on the diversity, functioning and evolution of plant communities. Biol. Rev. Camb. Philos. Soc. 90, 297-313. https://doi.org/10.1111/brv.12110

Thompson, S., Katul, G., 2009. Secondary seed dispersal and its role in landscape organization. Geophys. Res. Lett. 36, L02402. https://doi.org/10.1029/2008GL036044

Tirado, R., Pugnaire, F.I., 2005. Community structure and positive interactions in constraining environments. Oikos 111, 437-444. https://doi.org/10.1111/j.1600-0706.2005.14094.x

Valiente-Banuet, A., Rumebe, A. V., Verdu, M., Callaway, R.M., 2006. Modern Quaternary plant lineages promote diversity through facilitation of ancient Tertiary lineages. Proc. Natl. Acad. Sci. 103, 16812-16817. https://doi.org/10.1073/pnas.0604933103

Venable, D.L., Flores-Martinez, A., Muller-Landau, H.C., Barron-Gafford, G., Becerra, J.X., 
2008. Seed dispersal of desert annuals. Ecology 89, 2218-2227. https://doi.org/10.1890/070386.1

Whittaker, R.H., Niering, W.A., 1975. Vegetation of the Santa Catalina Mountains, Arizona. V. biomass, production, and diversity along the elevation gradient. Ecology 56, 771-790. https://doi.org/10.2307/1936291

Wiens, J.J., 2011. The niche, biogeography and species interactions. Philos. Trans. R. Soc. B Biol. Sci. 366, 2336-2350. https://doi.org/10.1098/rstb.2011.0059

Wisz, M.S., Pottier, J., Kissling, W.D., Pellissier, L., Lenoir, J., Damgaard, C.F., Dormann, C.F., Forchhammer, M.C., Grytnes, J.A., Guisan, A., Heikkinen, R.K., Høye, T.T., Kühn, I., Luoto, M., Maiorano, L., Nilsson, M.C., Normand, S., Öckinger, E., Schmidt, N.M., Termansen, M., Timmermann, A., Wardle, D.A., Aastrup, P., Svenning, J.C., 2013. The role of biotic interactions in shaping distributions and realised assemblages of species: Implications for species distribution modelling. Biol. Rev. 88, 15-30. https://doi.org/10.1111/j.1469-185X.2012.00235.x

\section{Appendix}

Table S1: The ANOVA table for species richness.

Table S2: The ANOVA table for species richness of theprobabilistic null model. Table S3: The ANOVA table for $\mathrm{z}$-scores of the probabilistic null model. Table S4: List of species. Figure S1: Identical analysis of Figure 3 with \pm 100 elevation categories. Figure S2: Identical analysis of Figure 3 with $\pm \mathbf{3 0 0}$ elevation categories. Figure S3: Identical analysis of Figure 2 after removing shrubs greater than $12 \mathbf{~ m}^{2}$. Figure S4: Boxplot of null communities built from the probability model. 


\section{Figure captions}

Fig. 1 Microclimate under nurse-plants increase with age providing establishment for species from different elevations. The distribution of a species is determined by a matching of species characteristics to specific environmental conditions (i.e. environmental filtering). We propose that nurse-plants mediate species from outside their optimal environment and that facilitation is more important the further from that optimal environment a species deviates (greater physiological strain). Here we show an example that species from higher elevations (colours represent increasing elevation and decreasing aridity from brown to white) can persist at lower elevations due to environmental modification by nurse-plants and that older nurse-plants have more microsites beneath them that facilitate a greater range of species (i.e. only local species from the same site under younger Retama and a range of high elevation to local species under older Retama). Arrows match elevation colours to Retama size.

Fig. 2 Elevation range and composition of species under Retama and open sites. The site used in this study is at 630 masl. Expansion of home elevation was calculated as the difference in median home elevation reported for the species and the elevation of the site. (a) The number of species found under all Retama (black) and in open areas (grey) that originated from elevations greater than $1000 \mathrm{~m}$ above the site $(-1000 \mathrm{~m}$ difference) to $500 \mathrm{~m}$ below the site $(500 \mathrm{~m}$ difference). There were 104 species in total found under Retama shrubs and 61 species in total in open areas. (b) The proportion of the number of species found under Retama relative to the total species richness found from that median elevation both under Retama and in open sites. The black line represents a loess smoother with 95\% CI. (d) The composition was statistically different between open and Retama communities as well as from older to younger Retama. Numbers represent Retama age, and the line represents the directional effect of age.

Fig. 3 Beneficiary species richness as a function of Retama age and origin elevation. Species richness (95\% CI) significantly increased with Retama age, after controlling for the effects of area, for beneficiary species originating at elevations from and above the site but not from below the site (a). Average species richness was lowest for beneficiary species originating from low elevation (b), highest for beneficiary species from the home elevation (c) and intermediate for beneficiary species from high elevation (d). Therefore, older Retama had more species than younger Retama and expanded the elevation range of more species than younger Retama. 


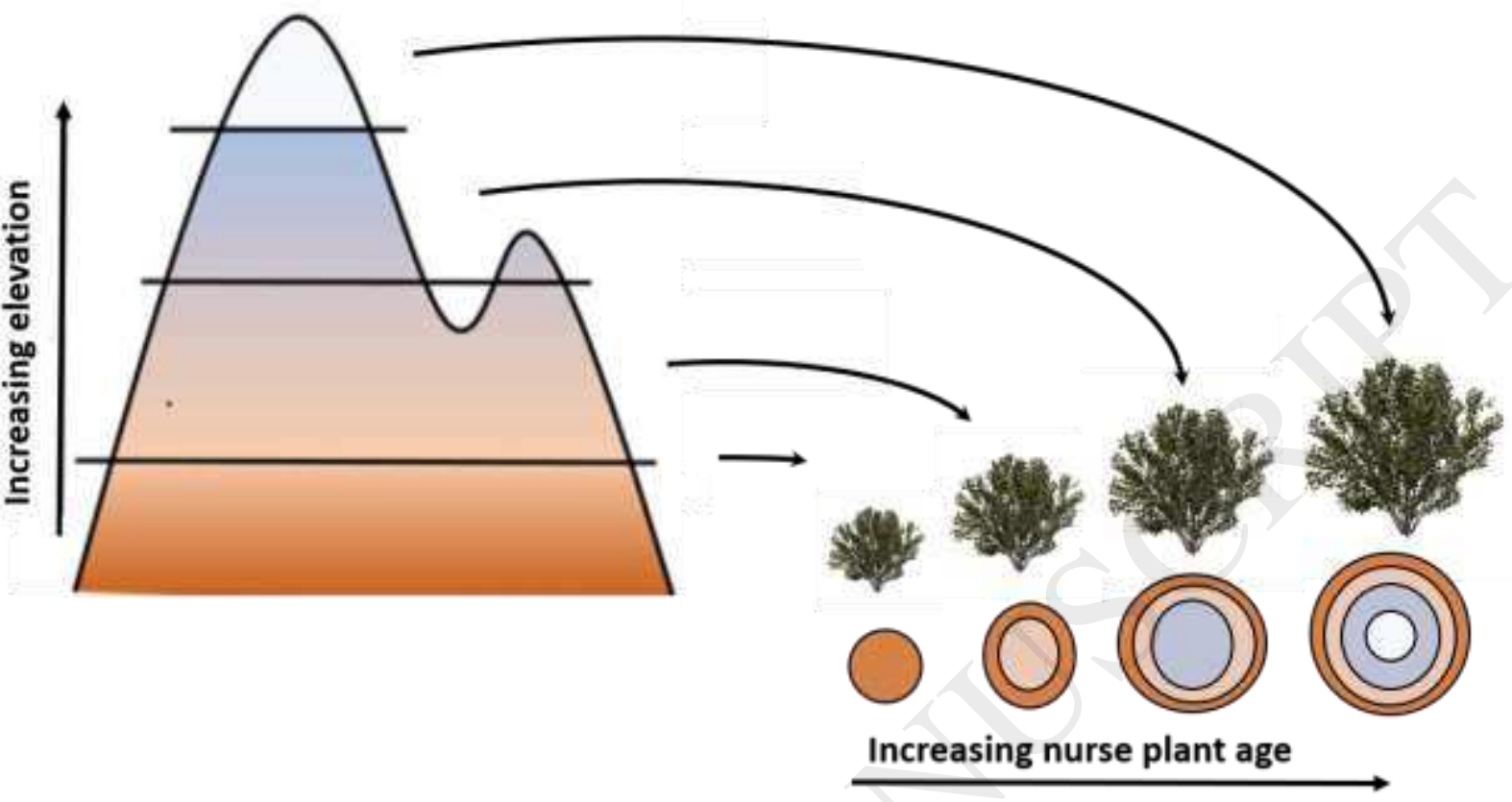

Fig. 1 Microclimate under nurse-plants increase with age providing establishment for species from different elevations. The distribution of a species is determined by a matching of species characteristics to specific environmental conditions (i.e. environmental filtering). We propose that nurse-plants mediate species from outside their optimal environment and that facilitation is more important the further from that optimal environment a species deviates (greater physiological strain). Here we show an example that species from higher elevations (colours represent increasing elevation and decreasing aridity from brown to white) can persist at lower elevations due to environmental modification by nurse-plants and that older nurse-plants have more microsites beneath them that facilitate a greater range of species (i.e. only local species from the same site under younger Retama and a range of high elevation to local species under older Retama). Arrows match elevation colours to Retama size. 


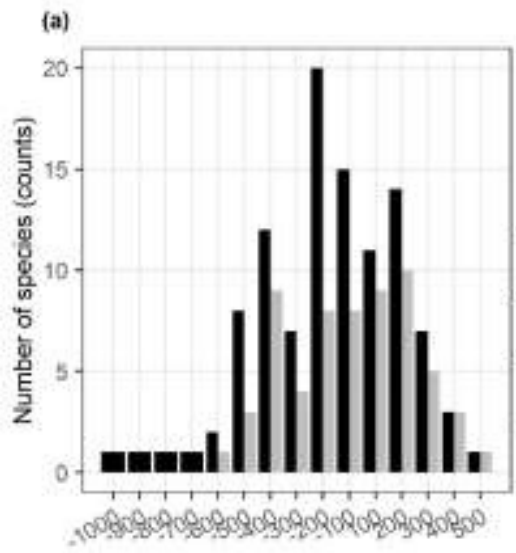

Difference from median elevation (b)

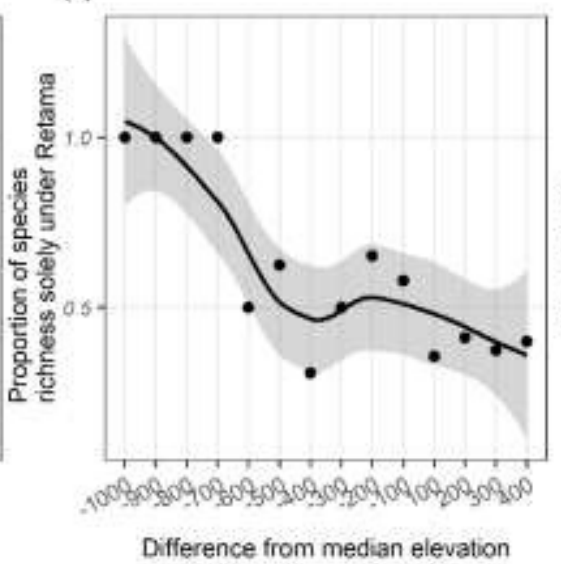

(c)

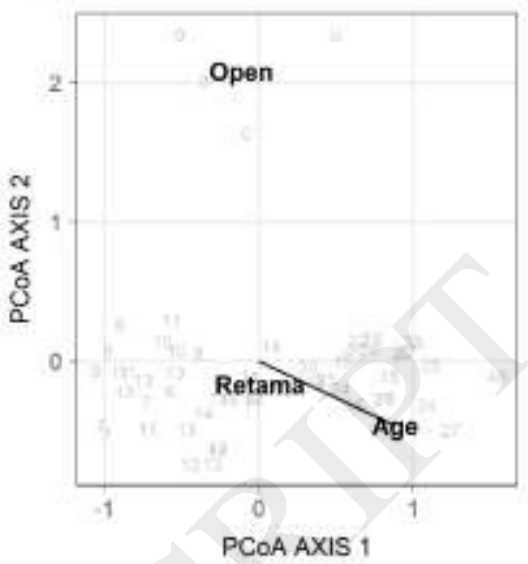

Fig. 2 Elevation range and composition of species under Retama and open sites. The site used in this study is at 630 masl. Expansion of home elevation was calculated as the difference in median home elevation reported for the species and the elevation of the site. (a) The number of species found under all Retama (black) and in open areas (grey) that originated from elevations greater than $1000 \mathrm{~m}$ above the site $(-1000 \mathrm{~m}$ difference) to $500 \mathrm{~m}$ below the site $(500 \mathrm{~m}$ difference). There were 104 species in total found under Retama shrubs and 61 species in total in open areas. (b) The proportion of the number of species found under Retama relative to the total species richness found from that median elevation both under Retama and in open sites. The black line represents a loess smoother with 95\% CI. (d) The composition was statistically different between open and Retama communities as well as from older to younger Retama. Numbers represent Retama age, and the line represents the directional effect of age. 

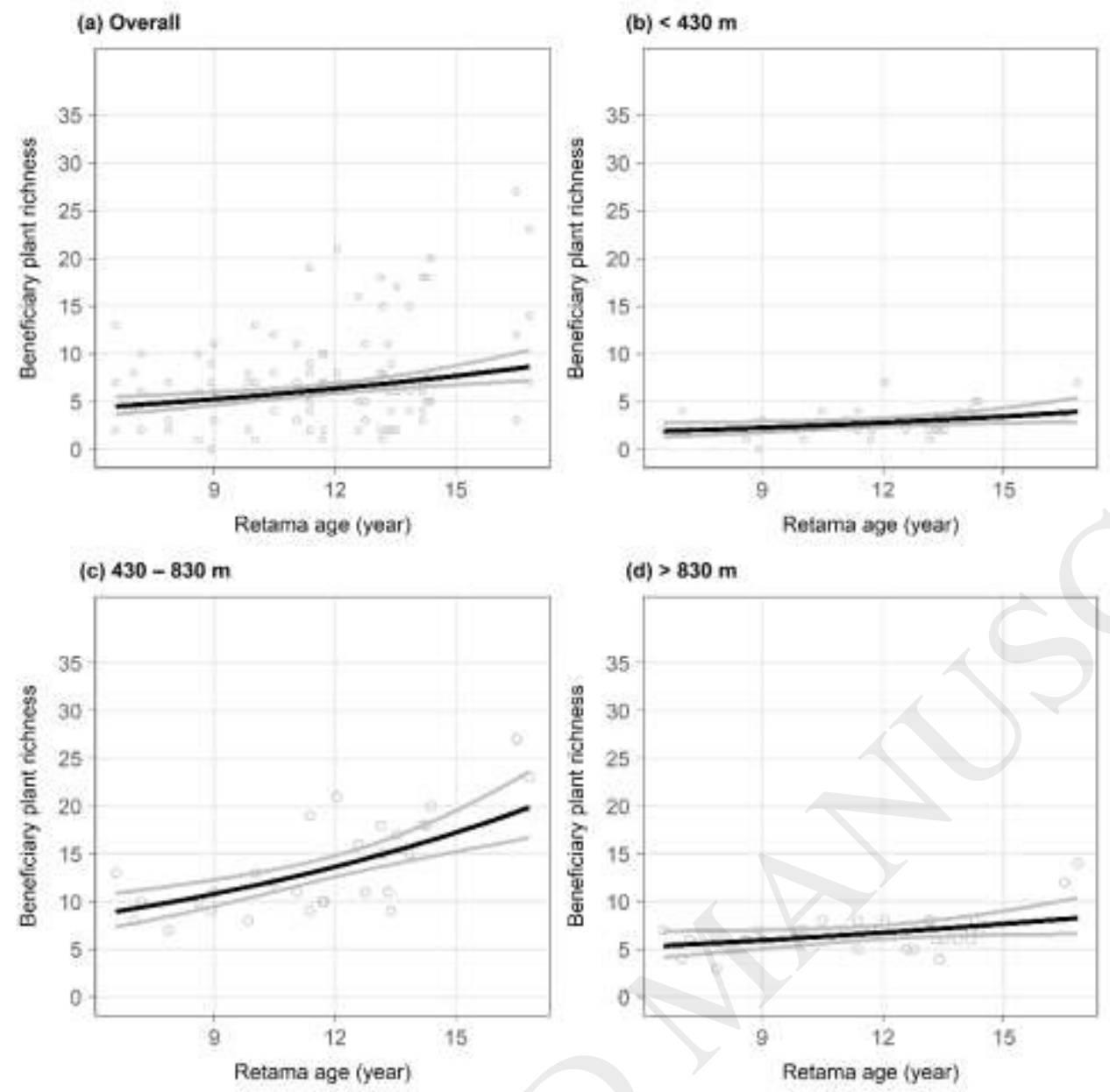

Fig. 3 Beneficiary species richness as a function of Retama age and origin elevation. Species richness (95\% CI) significantly increased with Retama age, after controlling for the effects of area, for beneficiary species originating at elevations from and above the site but not from below the site (a). Average species richness was lowest for beneficiary species originating from low elevation (b), highest for beneficiary species from the home elevation (c) and intermediate for beneficiary species from high elevation (d). Therefore, older Retama had more species than younger Retama and expanded the elevation range of more species than younger Retama. 


\section{Appendix 1}

Table S1: The ANOVA table for species richness.

Table S2: The ANOVA table for species richness of theprobabilistic null model.

Table S3: The ANOVA table for $z$-scores of the probabilistic null model.

Table S4: List of species.

Figure S1: Identical analysis of Figure 3 with \pm 100 elevation categories.

Figure S2: Identical analysis of Figure 3 with \pm 300 elevation categories.

Figure S3: Identical analysis of Figure 2 after removing shrubs greater than $12 \mathbf{~ m}^{2}$.

Figure S4: Boxplot of null communities built from the probability model.

Facilitation mediates species presence beyond their environmental optimum

Michael J. O’Brien ${ }^{1 *}$, Luis Fernando Tavares de Menezes $^{2}$, Kari Anne Bråthen ${ }^{3}$, Francisco I.

Pugnaire $^{1 *}$

${ }^{1}$ Estación Experimental de Zonas Áridas, Consejo Superior de Investigaciones Científicas,

Carretera de Sacramento s/n, E-04120 La Cañada, Almería, Spain

${ }^{2}$ Universidade Federal do Espírito Santo, Centro Universitário Norte do Espírito Santo, BR 101

Norte, Km 60 - Bairro Litorâneo, São Mateus, 29.932-540, Espírito Santo - Brasil

${ }^{3}$ Department of Arctic and Marine Biology, UiT, The Arctic University of Norway, NO-9037

Troms $\phi$, Norway

*corresponding authors: mikey.j.obrien@gmail.com and fip@eeza.csic.es 
Table S1. The ANOVA tables of Wald statistics from the mixed-effects model of species richness using a Poisson distribution and log link function with a covariate for canopy area.

\begin{tabular}{cccc}
\hline Source of variation & d.f. & denominator d.f. & F \\
\hline Retama area & 1 & 44.2 & $57.4 * * *$ \\
Retama age & 1 & 39.8 & $14.6^{* * *}$ \\
Elevation & 2 & 74.5 & $596.4 * * *$ \\
Age x elevation & 2 & 62.1 & $4.5 *$ \\
\hline Variance components & Var. & SE & \\
\hline Shrub & 0.05 & 0.01 & \\
\hline Shrub:elevation & 0.00 & 0.01 & \\
Residual & 0.44 & 0.11 &
\end{tabular}

d.f., degrees of freedom; denominator d.f., denominator degrees of freedom,

F, conditional F-statistic; Var., variance component estimate and SE, standard errors for random effects; $* * \mathrm{P}<0.01, * * * \mathrm{P}<0.001$ 
Table S2. The ANOVA tables of Wald statistics from the mixed-effects model of species richness compared to a probabilistic null model using a Poisson distribution and log link function for a) low, b) home and c) high elevation communities.

\begin{tabular}{|c|c|c|c|}
\hline Source of variation & d.f. & denominator d.f. & $\mathbf{F}$ \\
\hline \multicolumn{4}{|l|}{$\mathbf{a}$} \\
\hline Sampled area & 1 & 32995 & $2322 * * *$ \\
\hline Age & 1 & 32995 & $70 * * *$ \\
\hline Variance components & Var. & SE & \\
\hline Simulation & -0.001 & 0.000 & \\
\hline Residual & 0.791 & 0.006 & \\
\hline \multicolumn{4}{|l|}{$\mathbf{b}$} \\
\hline Sampled area & 1 & 32998 & $3395 * * *$ \\
\hline Age & 1 & 32998 & $3101 * * *$ \\
\hline Variance components & Var. & SE & \\
\hline Simulation & 0.000 & 0.000 & \\
\hline Residual & 0.877 & 0.007 & \\
\hline \multicolumn{4}{|l|}{$\mathbf{c}$} \\
\hline Sampled area & 1 & 32999 & $327 * * *$ \\
\hline Age & 1 & 32999 & $1538 * * *$ \\
\hline Variance components & Var. & SE & \\
\hline Simulation & 0.000 & 0.000 & \\
\hline Residual & 0.818 & 0.006 & \\
\hline
\end{tabular}


Table S3. The ANOVA tables of linear model of z-scores from a probabilistic null model as a function of Retama age for a) low, b) home and c) high elevation communities.

\begin{tabular}{ccccc}
\hline & Source of variation & d.f. & denominator d.f. & F \\
\hline a & & & & \\
& Age & 1 & SE & $8.3 * *$ \\
\hline & Variance components & Var. & 0.06 & \\
\hline & Residual & 0.30 & 52 & $48.7 * * *$ \\
\hline b & & 1 & SE & \\
\hline & Age & Var. & 0.12 & \\
\hline & Residual & 0.60 & $5.4 * *$ \\
\hline c & Age & 1 & 52 & \\
\hline & Variance components & Var. & SE & \\
\hline & Residual & 0.32 & 0.06 & \\
\hline
\end{tabular}

d.f., degrees of freedom; denominator d.f., denominator degrees of freedom,

F, conditional F-statistic; Var., variance component estimate and SE, standard errors for random effects; $* * \mathrm{P}<0.01, * * * \mathrm{P}<0.001$ 
Table S4. Species list and elevation. The starred (*) species was removed from analysis due to uncertainty over the subspecies.

\begin{tabular}{|c|c|c|c|c|c|c|}
\hline Species & $\begin{array}{l}\text { Lower } \\
\text { limit }\end{array}$ & $\begin{array}{l}\text { Upper } \\
\text { limit }\end{array}$ & Median & $\begin{array}{l}\text { Saltador } \\
\text { elevation }\end{array}$ & $\begin{array}{l}\text { Elevation } \\
\text { difference }\end{array}$ & Site \\
\hline Alyssum_granatense & 1600 & 2100 & 1850 & 630 & -1220 & Retama \\
\hline Spergularia_rubra & 700 & 2500 & 1600 & 630 & -970 & Retama \\
\hline Juncus_bufonius & 0 & 3000 & 1500 & 630 & -870 & Retama \\
\hline Capsella bursa-pastoris & 0 & 2500 & 1250 & 630 & -620 & Retama \\
\hline Logfia_minima & 300 & 2100 & 1200 & 630 & -570 & Retama, Open \\
\hline Galium_spurium & 300 & 2000 & 1150 & 630 & -520 & Retama \\
\hline Andryala_ragusina & 0 & 2200 & 1100 & 630 & -470 & Retama, Open \\
\hline Cirsium_arvense & 300 & 1800 & 1050 & 630 & -420 & Retama \\
\hline Erodium cicutarium & 0 & 2100 & 1050 & 630 & -420 & Retama, Open \\
\hline Geranium_molle & 0 & 2100 & 1050 & 630 & -420 & Retama \\
\hline Paronychia_suffruticosa & 100 & 2000 & 1050 & 630 & -420 & Retama, Open \\
\hline Senecio_malacitanus & 0 & 2100 & 1050 & 630 & -420 & Retama \\
\hline Silene_portensis & 300 & 1800 & 1050 & 630 & -420 & Retama \\
\hline Sonchus_oleraceus & 0 & 2100 & 1050 & 630 & -420 & Retama \\
\hline Aegilops_truncialis & 300 & 1700 & 1000 & 630 & -370 & Retama \\
\hline Daucus_durieua & 300 & 1700 & 1000 & 630 & -370 & Retama \\
\hline Lamarkia_aurea & 0 & 2000 & 1000 & 630 & -370 & Retama, Open \\
\hline Leontodon_longirostris & 0 & 2000 & 1000 & 630 & -370 & Retama, Open \\
\hline Papaver_pinnatifidum & 0 & 2000 & 1000 & 630 & -370 & Retama, Open \\
\hline Paronychia_argentea & 0 & 2000 & 1000 & 630 & -370 & Retama, Open \\
\hline Rumex_induratus & 0 & 2000 & 1000 & 630 & -370 & Retama \\
\hline Silene_colorata & 300 & 1700 & 1000 & 630 & -370 & Retama, Open \\
\hline Clypeola_jonthlaspi & 0 & 1900 & 950 & 630 & -320 & Retama, Open \\
\hline Eryngium_ilicifolium & 0 & 1900 & 950 & 630 & -320 & Retama \\
\hline Petrorhagia_prolifera & 100 & 1800 & 950 & 630 & -320 & Open \\
\hline Sonchus_tenerrimus & 0 & 1900 & 950 & 630 & -320 & Retama, Open \\
\hline Trigonella_polyceratia & 0 & 1900 & 950 & 630 & -320 & Retama, Open \\
\hline Trifolium_scabrum & 0 & 1800 & 900 & 630 & -270 & Retama \\
\hline Thymus_baeticus & 0 & 1750 & 875 & 630 & -245 & Retama \\
\hline Carlina_corymbosa & 100 & 1600 & 850 & 630 & -220 & Retama \\
\hline Hypochaeris_glabra & 0 & 1700 & 850 & 630 & -220 & Retama, Open \\
\hline Medicago_minima & 0 & 1700 & 850 & 630 & -220 & Retama, Open \\
\hline Rumex_bucephalophorus & 0 & 1700 & 850 & 630 & -220 & Retama, Open \\
\hline Spergularia_purpurea & 100 & 1600 & 850 & 630 & -220 & Open \\
\hline Vulpia_hispanica & 0 & 1700 & 850 & 630 & -220 & Retama \\
\hline Aegilops_ovata & 100 & 1500 & 800 & 630 & -170 & Retama \\
\hline Anacyclus_clavatus & 100 & 1500 & 800 & 630 & -170 & Retama \\
\hline Atractylis_cancellata & 0 & 1600 & 800 & 630 & -170 & Retama \\
\hline Avena_sterilis & 0 & 1600 & 800 & 630 & -170 & Retama \\
\hline Centaurea_melitensis & 0 & 1600 & 800 & 630 & -170 & Retama \\
\hline
\end{tabular}




\begin{tabular}{|c|c|c|}
\hline Cynodon_dactylon & 0 & 1600 \\
\hline Dactylis_glomerata & 0 & 1600 \\
\hline Helianthemum_ledifolium & 0 & 1600 \\
\hline Lagurus_ovatus & 0 & 1600 \\
\hline Neatostema_apulum & 0 & 1600 \\
\hline Scabiosa_monspeliensis & 0 & 1600 \\
\hline Silene_tridentata & 100 & 1500 \\
\hline Bromus_rubens & 0 & 1500 \\
\hline Catapodium_rigidum & 0 & 1500 \\
\hline Euphorbia_falcata & 0 & 1500 \\
\hline Linum_strictum & 0 & 1500 \\
\hline Malcolmia_africana & 0 & 1500 \\
\hline Marrubium_vulgare & 0 & 1500 \\
\hline Medicago_truncatula & 0 & 1500 \\
\hline Plantago_afra & 0 & 1500 \\
\hline Plantago_albicans & 0 & 1500 \\
\hline Reseda_undata & 0 & 1500 \\
\hline Silene_nocturna & 0 & 1500 \\
\hline Bromus_diandrus & 0 & 1400 \\
\hline Chenopodium_murale & 0 & 1400 \\
\hline Euphorbia_helioscopia & 0 & 1400 \\
\hline Lathyrus_angulatus & 0 & 1400 \\
\hline Ononis_ornithopodioides & 0 & 1400 \\
\hline Reichardia_intermedia & 0 & 1400 \\
\hline Tolpis_umbellata & 0 & 1400 \\
\hline Valantia_muralis & 0 & 1400 \\
\hline Artemisia_barrelieri & 50 & 1300 \\
\hline Anthyllis_cytisoides & 0 & 1300 \\
\hline Convolvulus_althaeoides & 0 & 1300 \\
\hline Crassula_tillaea & 0 & 1300 \\
\hline Erodium_malacoides & 0 & 1300 \\
\hline Hypecoum_imberbe & 200 & 1500 \\
\hline Lasiopogon_muscoides & 300 & 1000 \\
\hline Logfia_clementei & 0 & 1300 \\
\hline Lolium_rigidum & 200 & 1100 \\
\hline Reichardia_tingitana & 0 & 1300 \\
\hline Urospermum_picroides & 0 & 1300 \\
\hline Asphodelus_fistulosus & 0 & 1200 \\
\hline $\begin{array}{l}\text { Asterolinon_linum- } \\
\text { stellatum }\end{array}$ & 0 & 1200 \\
\hline Brachypodium_distachyon & 0 & 1200 \\
\hline Carrichtera_annua & 0 & 1200 \\
\hline Desmazeria_rigida & 0 & 1200 \\
\hline Foeniculum_vulgare & 0 & 1200 \\
\hline Hedypnois_cretica & 0 & 1200 \\
\hline
\end{tabular}

$\begin{array}{llc}630 & -170 & \text { Retama } \\ 630 & -170 & \text { Retama } \\ 630 & -170 & \text { Retama, Open } \\ 630 & -170 & \text { Retama } \\ 630 & -170 & \text { Retama } \\ 630 & -170 & \text { Retama } \\ 630 & -170 & \text { Retama } \\ 630 & -120 & \text { Retama, Open } \\ 630 & -120 & \text { Retama } \\ 630 & -120 & \text { Open } \\ 630 & -120 & \text { Retama, Open } \\ 630 & -120 & \text { Retama } \\ 630 & -120 & \text { Retama } \\ 630 & -120 & \text { Retama, Open } \\ 630 & -120 & \text { Retama } \\ 630 & -120 & \text { Open } \\ 630 & -120 & \text { Retama, Open } \\ 630 & -120 & \text { Open } \\ 630 & -70 & \text { Retama } \\ 630 & -70 & \text { Retama } \\ 630 & -70 & \text { Retama, Open } \\ 630 & -70 & \text { Retama } \\ 630 & -70 & \text { Retama } \\ 630 & -70 & \text { Retama } \\ 630 & -70 & \text { Retama } \\ 630 & -70 & \text { Retama } \\ 630 & -45 & \text { Retama, Open } \\ 630 & -20 & \text { Retama } \\ 630 & -20 & \text { Retama } \\ 630 & -20 & \text { Open } \\ 630 & -20 & \text { Open } \\ 630 & -20 & \text { Open } \\ 630 & -20 & \text { Open } \\ 630 & -20 & \text { Retama, Open } \\ 630 & -20 & \text { Retama } \\ 630 & -20 & \text { Retama, Open } \\ 630 & -20 & \text { Retama } \\ 630 & 30 & \text { Open } \\ 630 & & \\ 630 & -20 & \end{array}$

$630 \quad 30$

630

30

Retama, Open

Retama

$630 \quad 30$

630

30

Retama, Open

Open

Retama

Retama 


\begin{tabular}{|c|c|c|c|c|c|c|}
\hline Lycocarpus_fugax & 400 & 800 & 600 & 630 & 30 & Retama, Open \\
\hline Pipthaterum_miliaceum & 0 & 1200 & 600 & 630 & 30 & Retama, Open \\
\hline Plantago_lagopus & 0 & 1200 & 600 & 630 & 30 & Retama, Open \\
\hline Avena_barbata & 0 & 1100 & 550 & 630 & 80 & Retama, Open \\
\hline Gynandriris_sisyrinchium & 0 & 1100 & 550 & 630 & 80 & Open \\
\hline Lobularia_maritima & 0 & 1100 & 550 & 630 & 80 & Retama \\
\hline Papaver_hybridum & 0 & 1100 & 550 & 630 & 80 & Retama \\
\hline Atractylis_humilis & 0 & 1000 & 500 & 630 & 130 & Retama \\
\hline Echium_creticum & 0 & 1000 & 500 & 630 & 130 & Retama, Open \\
\hline Leysera_leyseroides & 0 & 1000 & 500 & 630 & 130 & Retama, Open \\
\hline Loeflingia_hispanica & 0 & 1000 & 500 & 630 & 130 & Retama \\
\hline Malva_parviflora & 0 & 1000 & 500 & 630 & 130 & Retama \\
\hline Schismus_barbatus & 0 & 1000 & 500 & 630 & 130 & Retama \\
\hline Silene_decipiens & 0 & 1000 & 500 & 630 & 130 & Retama, Open \\
\hline Silene_sclerocarpa & 0 & 1000 & 500 & 630 & 130 & Open \\
\hline Stipa_capensis & 0 & 1000 & 500 & 630 & 130 & Retama, Open \\
\hline $\begin{array}{l}\text { Trigonella_foenum- } \\
\text { graecum }\end{array}$ & 400 & 600 & 500 & 630 & 130 & Open \\
\hline Asphodelus_tenuifolius & 0 & 900 & 450 & 630 & 180 & Retama, Open \\
\hline Calendula_tripterocarpa & 0 & 900 & 450 & 630 & 180 & Retama, Open \\
\hline Cistanche_phelypaea & 0 & 900 & 450 & 630 & 180 & Retama \\
\hline Herniaria_fontanesii & 0 & 900 & 450 & 630 & 180 & Retama \\
\hline Hordeum_leporinum & 0 & 900 & 450 & 630 & 180 & Retama, Open \\
\hline Linaria_nigricans & 0 & 900 & 450 & 630 & 180 & Open \\
\hline Matthiola_parviflora & 0 & 900 & 450 & 630 & 180 & Retama \\
\hline Erodium_chium & 0 & 800 & 400 & 630 & 230 & Retama, Open \\
\hline Eryngium_campestre & 0 & 800 & 400 & 630 & 230 & Retama, Open \\
\hline Ifloga_spicata & 0 & 800 & 400 & 630 & 230 & Open \\
\hline Lavandula_multifida & 0 & 800 & 400 & 630 & 230 & Retama \\
\hline Limonium_thouinii & 0 & 800 & 400 & 630 & 230 & Retama \\
\hline Notoceras_bicorne & 0 & 800 & 400 & 630 & 230 & Retama \\
\hline Ononis_viscosa & 0 & 800 & 400 & 630 & 230 & Retama, Open \\
\hline Rostraria_pumila & 0 & 800 & 400 & 630 & 230 & Retama, Open \\
\hline Diplotaxis_ilorcitana & 0 & 600 & 300 & 630 & 330 & Retama, Open \\
\hline Leontodon_hispidulus & 0 & 600 & 300 & 630 & 330 & Retama \\
\hline Linaria_oligantha & 0 & 600 & 300 & 630 & 330 & Open \\
\hline Plantago_ovata & 0 & 500 & 250 & 630 & 380 & Open \\
\hline Volutaria_lippii & 0 & 500 & 250 & 630 & 380 & Retama \\
\hline Silene_littorea & 0 & 400 & 200 & 630 & 430 & Retama, Open \\
\hline Polycarpon_tetraphyllum* & 0 & 50 & 25 & 630 & 605 & Retama \\
\hline
\end{tabular}


(a) Overall

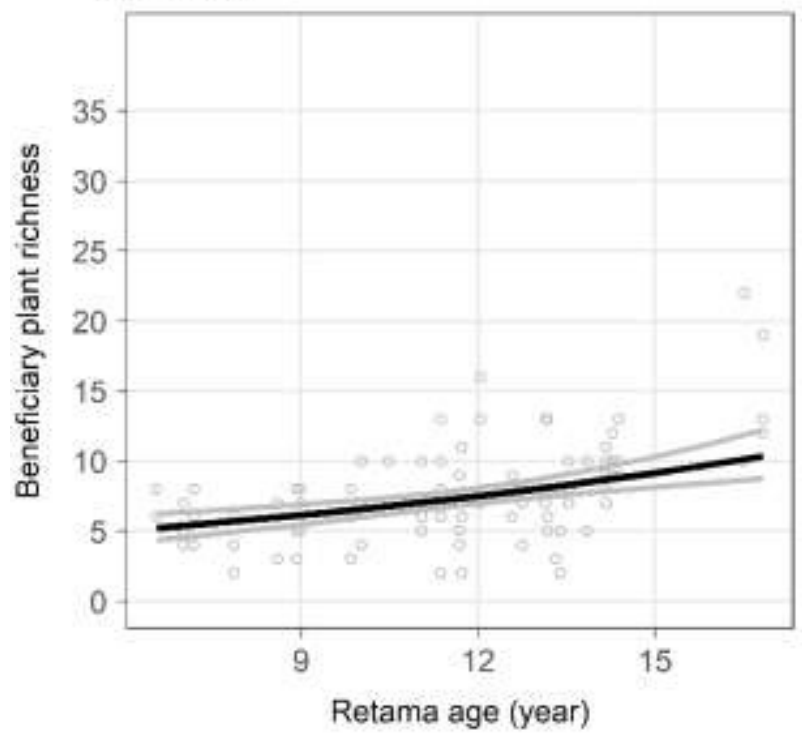

(c) $530-730 \mathrm{~m}$

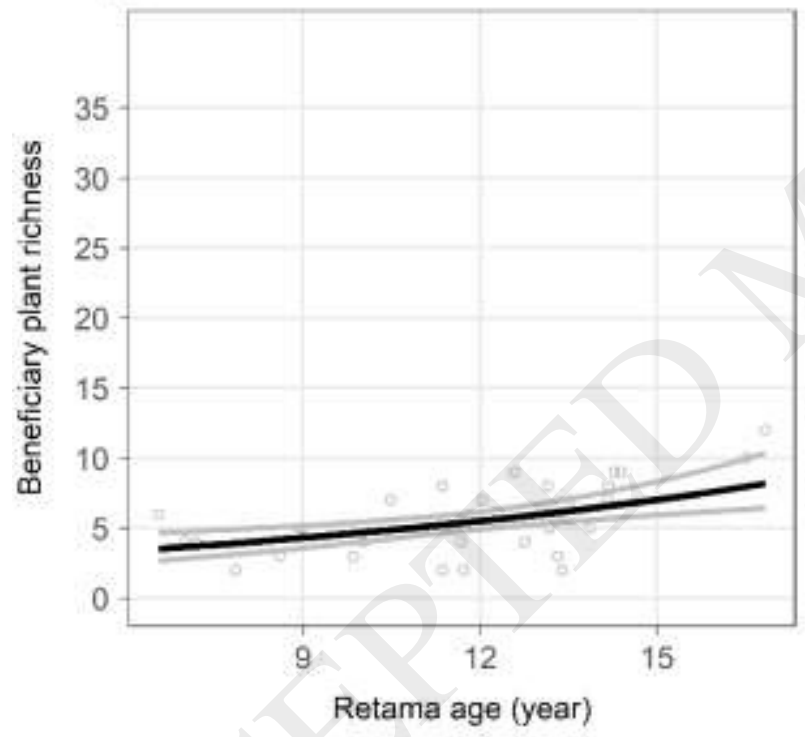

(b) $<530 \mathrm{~m}$

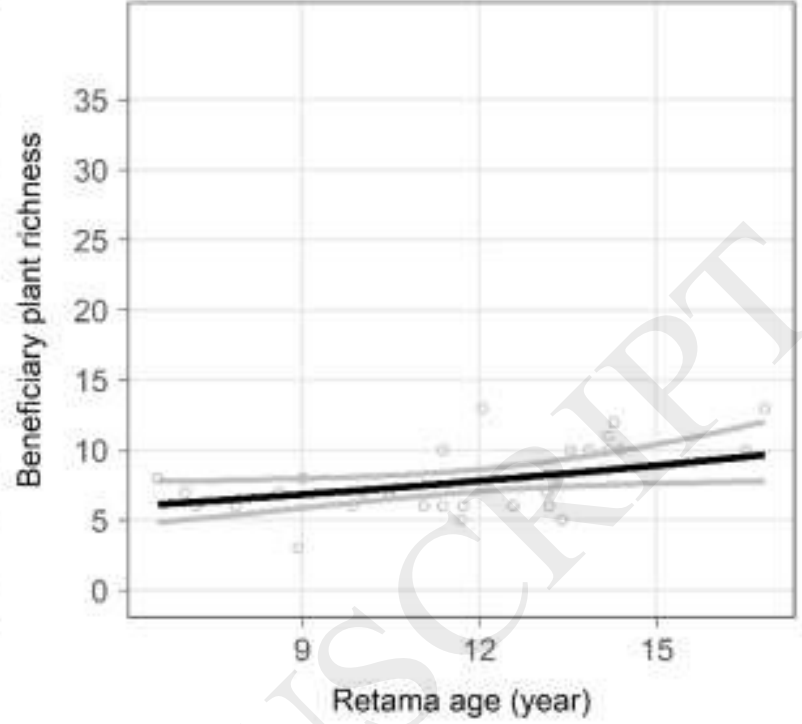

(d) $>730 \mathrm{~m}$

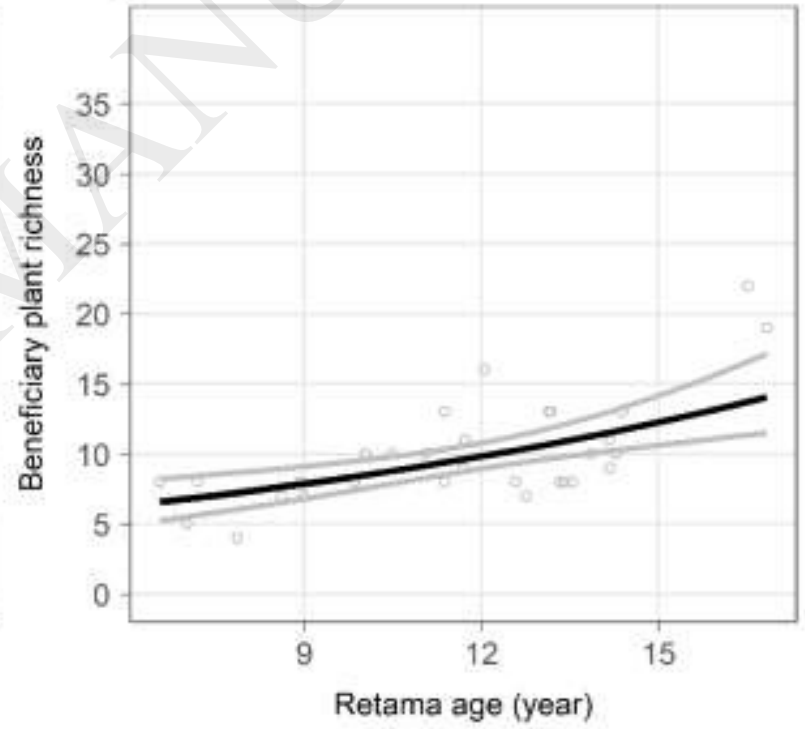

Figure S1. Beneficiary species richness as a function of Retama age and origin elevation $\mathbf{\$ 1 0 0}$ home elevation. Species richness (95\% CI) significantly increased with Retama age, after controlling for the effects of area, for beneficiary species originating at elevations from and above the site but not from below the site (a). Average species richness was lowest for beneficiary species originating from low elevation (b), highest for beneficiary species from the home elevation (c) and intermediate for beneficiary species from high elevation (d). Therefore, older Retama had more species than younger Retama and expanded the elevation range of more species than younger Retama. 
(a) Overall

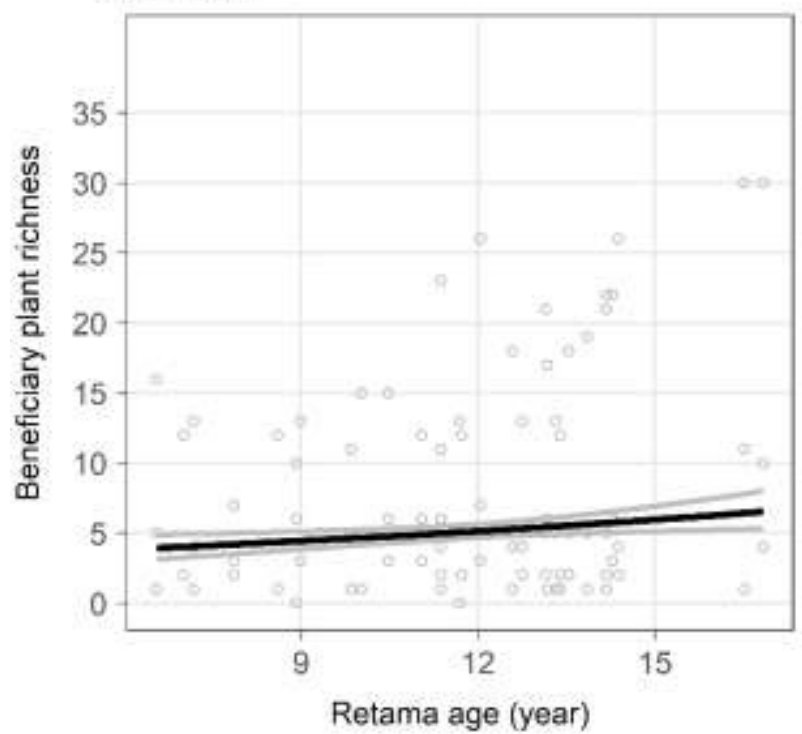

(c) $330-930 \mathrm{~m}$

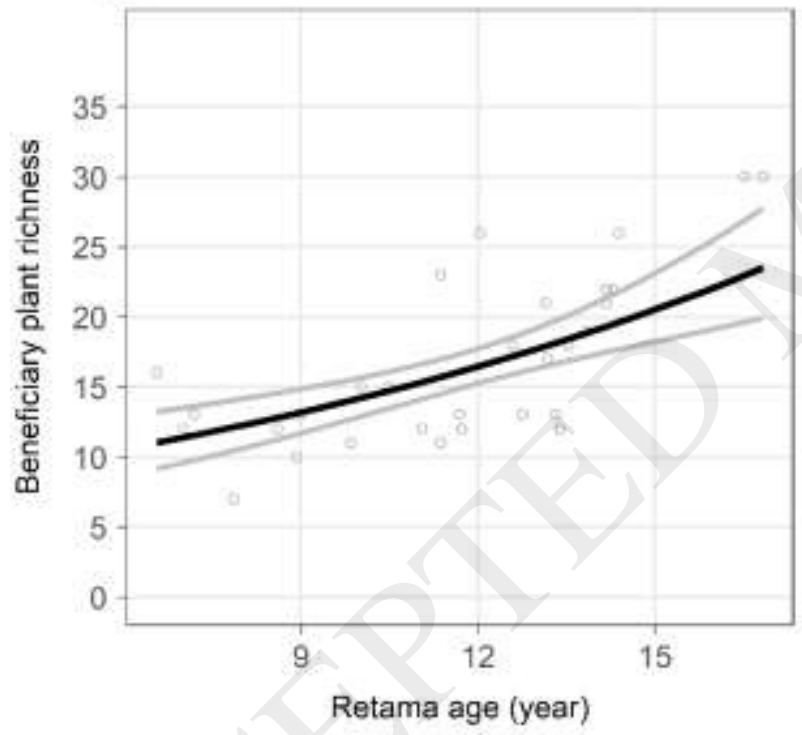

(b) $<330 \mathrm{~m}$

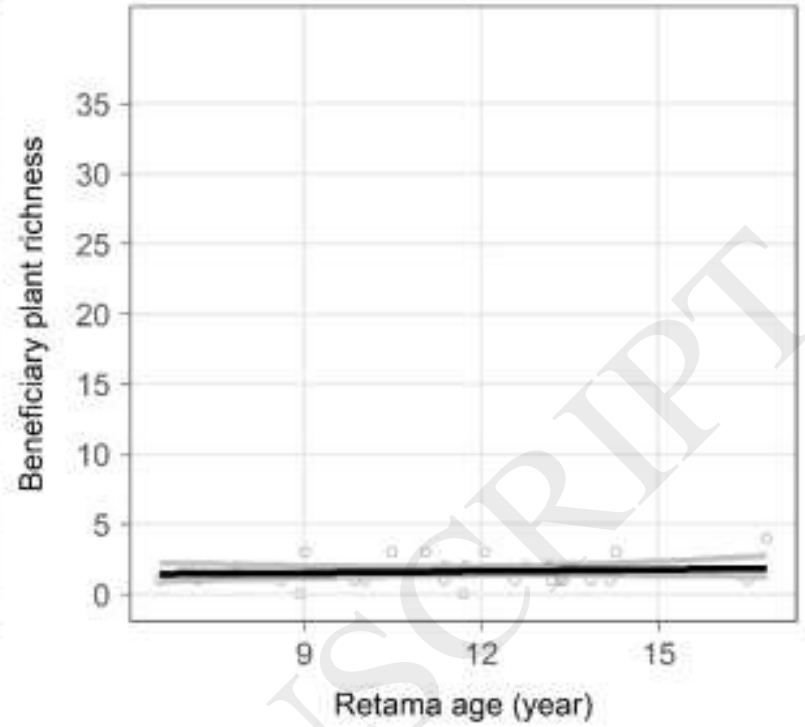

(d) $>930 \mathrm{~m}$

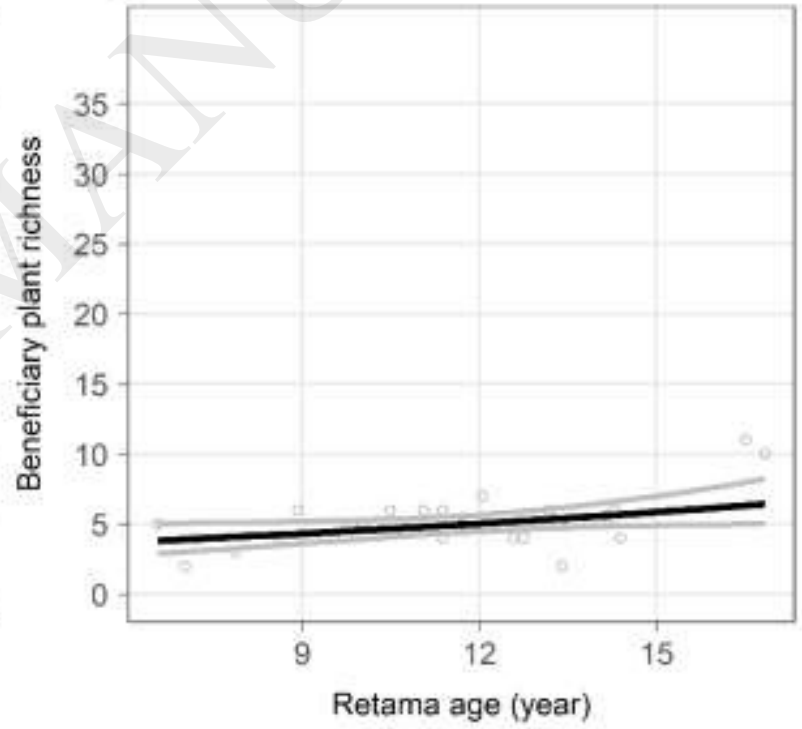

Figure S2. Beneficiary species richness as a function of Retama age and origin elevation $\mathbf{\pm 3 0 0}$ home elevation. Species richness (95\% CI) significantly increased with Retama age, after controlling for the effects of area, for beneficiary species originating at elevations from and above the site but not from below the site (a). Average species richness was lowest for beneficiary species originating from low elevation (b), highest for beneficiary species from the home elevation (c) and intermediate for beneficiary species from high elevation (d). Therefore, older Retama had more species than younger Retama and expanded the elevation range of more species than younger Retama. 
(a)

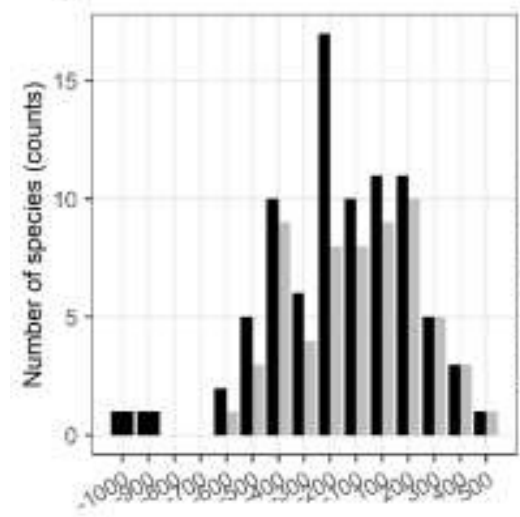

Difference from median elevation (b)

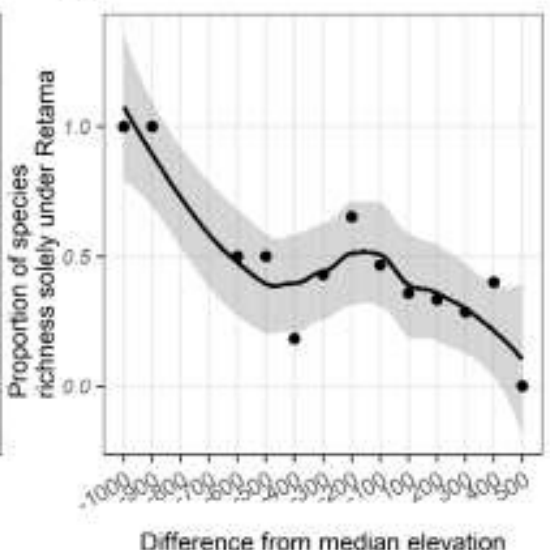

(c)

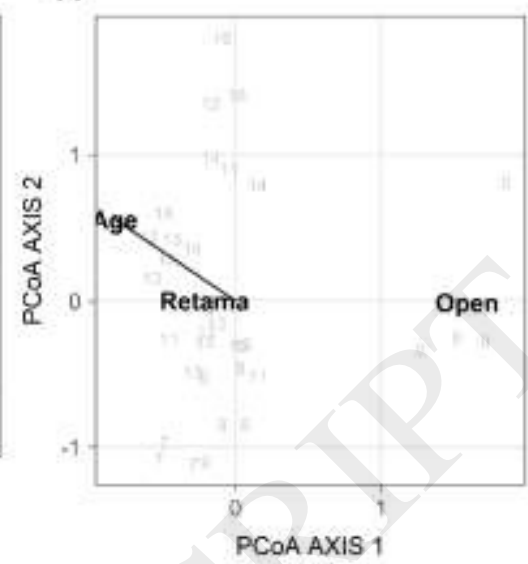

Figure S3. Elevation range and composition of species under Retama $12 \mathrm{~m}^{2}$ or less and open sites. The site used in this study is at 630 masl. Expansion of home elevation was calculated as the difference in median home elevation reported for the species and the elevation of the site. (a) The number of species found under all Retama (black) and in open areas (grey) that originated from elevations greater than $1000 \mathrm{~m}$ above the site $(-1000 \mathrm{~m}$ difference $)$ to $500 \mathrm{~m}$ below the site (500 $\mathrm{m}$ difference). There were 104 species in total found under Retama shrubs and 61 species in total in open areas. (b) The proportion of the number of species found under Retama relative to the total species richness found from that median elevation both under Retama and in open sites. The black line represents a loess smoother with 95\% CI. (d) The composition was statistically different between open and Retama communities as well as from older to younger Retama. Numbers represent Retama age, and the line represents the directional effect of age. 
(a)

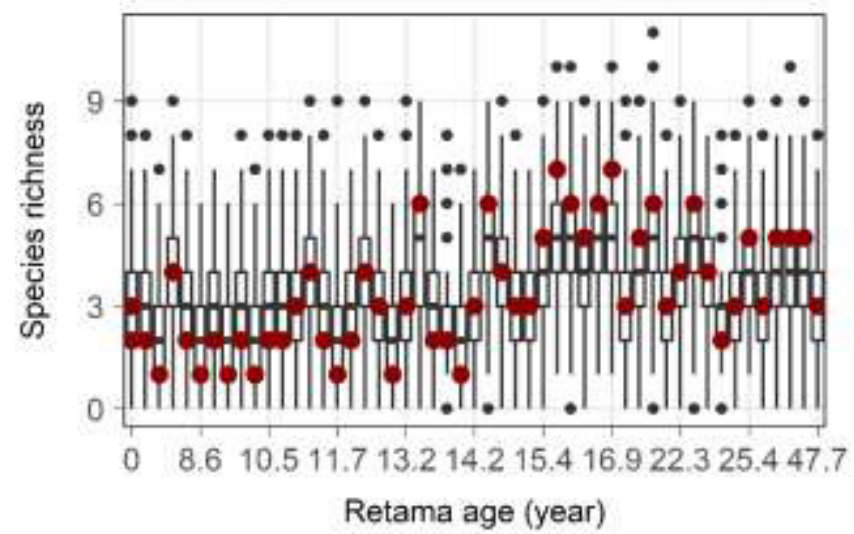

(b)

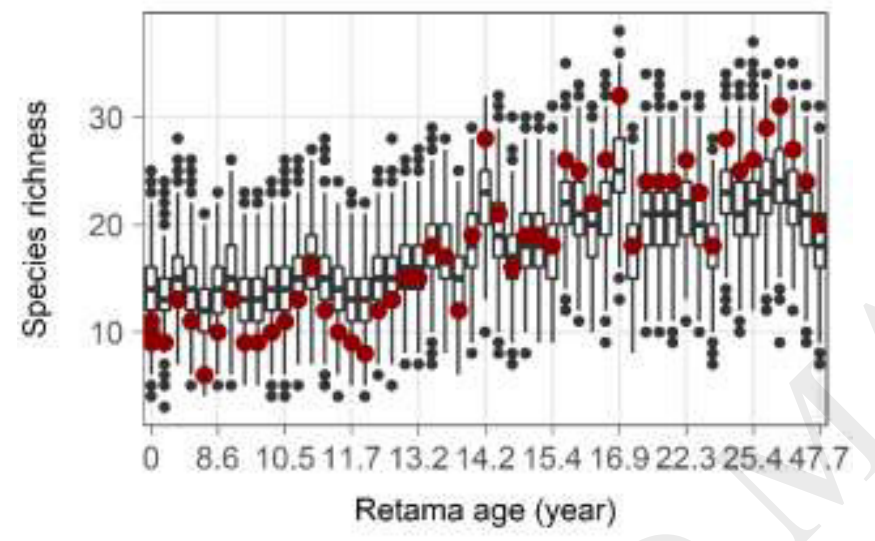

(c)

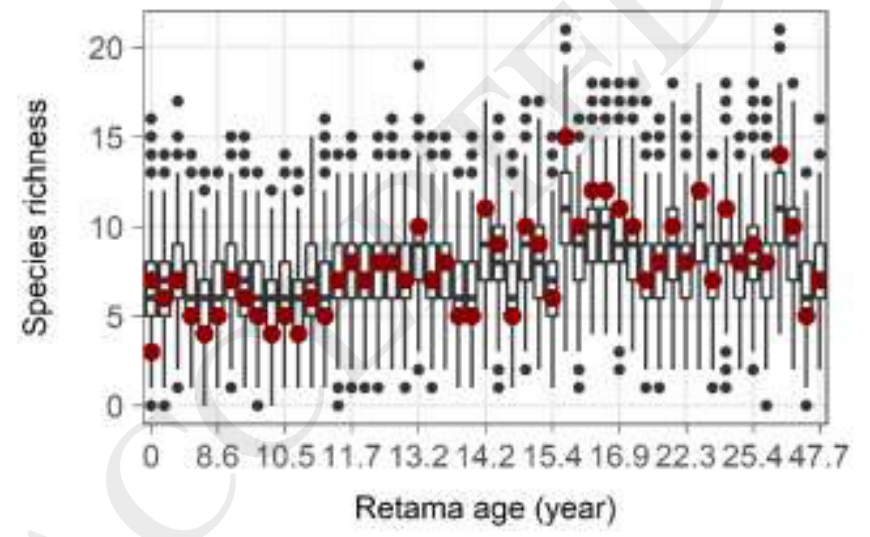

Figure S4. Boxplot of probability model. The distribution of random communities (boxwhisker plots with black points) built from the species matrix based on the probability model for the species originating from below, from and above the site. The red points are the observed species richness found at open sites (0 year old) and under Retama. 